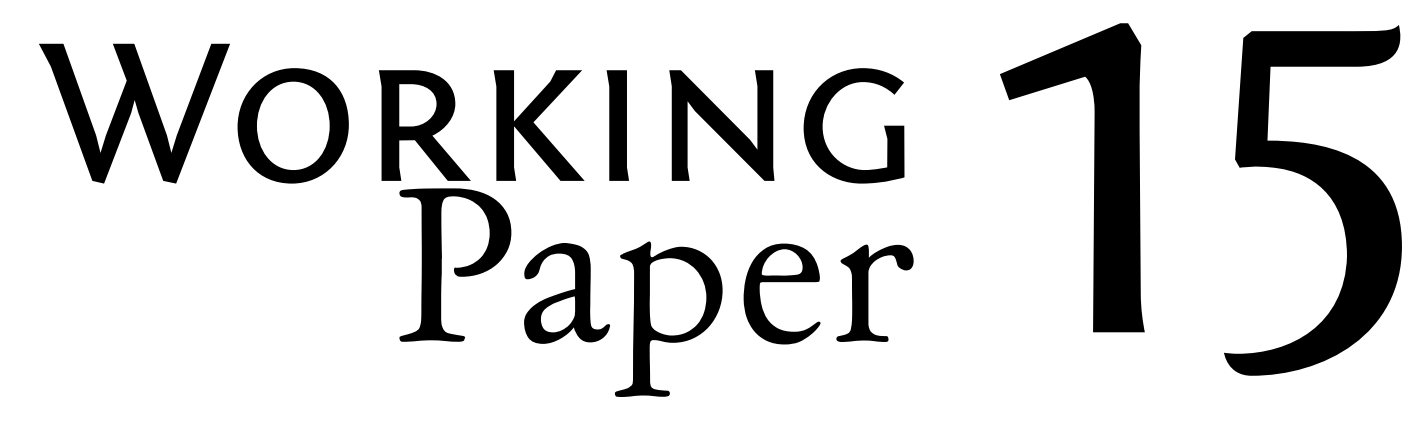

\title{
Contested paradigms of 'viability' in redistributive land reform: perspectives from southern Africa
}

Working paper for Livelihoods after Land Reform Project

Ben Cousins and Ian Scoones ${ }^{2}$

June 2009

1 Institute for Poverty, Land and Agrarian Studies (PLAAS), University of the Western Cape.

2 Institute of Development Studies, University of Sussex. 


\section{Contents}

Introduction

Modernisation and agricultural development in southern Africa: past and present

Framing viability: frameworks for assessing land and agrarian reform

Viability in redistributive land reform in southern Africa

Rethinking viability in southern African land reform

Conclusion

References

35 


\section{Introduction}

'Viability' is a key term in debates about land reform in southern African and beyond, and is used in relation to both individual projects and programmes. 'Viability' connotes 'successful' and 'sustainable' - but what is meant by viability in relation to land reform, and how have particular conceptions of viability informed state policies and planning approaches? More broadly, how have different notions of viability influenced the politics of land in recent years? This paper interrogates this influential but under-examined notion, reflecting on debates about the viability of land reform - and in particular about the relevance of smallscale, farming-based livelihoods - in southern Africa and more broadly3.

These questions are not merely of academic interest. How debates are framed and how success is judged has major implications. With arguments for and against redistributive land reform often hinging on the notion of viability, justifications for public expenditure and budget allocations can be offered if programmes and projects are deemed viable. Conversely, portraying redistributive land reform as 'unviable' provides a basis for arguments that this is a poor use of public funds. Yet, despite its centrality in debates about land reform, viability is rarely defined, and its precise meaning often remains obscure.

In southern Africa such debates tend to focus rather narrowly on farm productivity and economic returns. An implicit normative model in much usage in the region is the large-scale commercial farm, even when policies suggest that other scales and forms of production, such as smallholder farming, should be accommodated. The dominant framing of viability is embodied in technical recommendations around 'minimum farm sizes', 'economic units', and 'carrying capacities'. Methods and measures for appraisal of land reform - in planning, monitoring and evaluation - are defined in terms of marginal returns on investment or farm profitability. Processes of planning and implementation are framed by standard approaches to farm management and business plans developed for large-scale commercial farms, with the consequence that generalised statements indicating a role for other types of farming, such as small-scale, household-based systems, do not readily translate into programmatic support. This way of framing viability (and therefore 'success' and 'failure') is highly restrictive, but has far-reaching consequences, since the wider benefits and costs of land reform are rarely examined, the social and political dimensions are often ignored, and important cross-scale and linkage effects are not considered. Alternative ways of thinking about viability, drawn from a variety of analytical paradigms, are available, but have been much less influential in the region to date.

This article describes the origins of a hegemonic, 'large-scale commercial farm' version of viability and its influence on policy debates on land redistribution in South Africa, Namibia

3 The authors are members of a team investigating the livelihood impacts of redistributive land reform in South Africa, Zimbabwe and Namibia, over a three year period (2007-2009). The project also seeks to interrogate the meanings and impacts of alternative versions of viability within land reform policy frameworks. For details of the project and interim outputs, see www.lalr.org.za. An earlier version of this paper was presented to members of the regional team and the project reference group, and their feedback and advice is gratefully acknowledged. We would also like to thank the Economic and Social Research Council (ESRC) of the UK for their financial support for the project (project number RES-167-25-0037). 
and Zimbabwe. The discussion is located in the context of competing analytical paradigms for assessing land reform: neo-classical economics, new institutional economics, livelihoods approaches, welfarist perspectives, radical political economy and Marxism. Against this backdrop, we propose an approach to thinking about viability that draws on key insights from different frameworks, and we use these to suggest what a re-casting of the debate might imply for policy and practice in southern Africa today.

\section{Modernisation and agricultural development in southern Africa: past and present}

Key ideas in policy, such as the notion of viability, must be viewed in historical context. They emerge in particular places in relation to a range of debates and practices that are firmly embedded in historical experience. In southern Africa, discourses around viability have a long pedigree. From the colonial era to the present, dominant views on agricultural development have been based, implicitly or explicitly, on a modernisation narrative. Normative-political constructions of 'good', 'modern' and 'progressive' farmers and farming were implicit in linear models of economic development involving transitions from agriculture-based to industrial economies (cf. Rostow 1960, Schultz 1964, Johnston and Mellor, 1961). These constructs were, in turn, influenced by evolutionary views of technical change, in which low productivity farming shifts to intensive farming as a result of demographic pressure, and by technology transfer approaches, in which 'scientific' farming practices and technologies are provided to help modernise and civilise 'backward' farming systems (Scoones and Wolmer, 2002).

This narrative has often come to define understandings of agricultural development in Africa, in relation to technology (and a shift from 'backward' to 'modern' practices), markets (and a shift from self-provisioning to market based production and consumption) and economic productivity and growth (and a shift from 'subsistence' to commercial farming) (Scoones et al, 2005). Emphases have varied by setting and period, but a remarkable consistency is evident across time and space (cf. Ellis and Biggs, 2001). Striking continuities exist between colonial prescriptions on agricultural development in the 1920 or 305 , for example, and more recent exhortations about the need for a new, business-driven, commercial agriculture to replace older, subsistence modes (World Bank 2007).

State-led agricultural modernisation programmes peaked in the late 1940 s and 1950s, just before decolonisation was initiated, and a discourse of economic viability became widespread in this period. In Kenya, for example, the Swynnerton Plan of 1954 identified the ideal model as 'economic farm units' composed of a (yeoman) farmer, together with three labourers on a freehold property with selective credit and extension support (Williams 1996). Land was to be transferred to male farmers in order to boost cash crop production, particularly in the highlands (Throup, 1987). In South Africa, the 1955 Tomlinson Report on black ag- 
riculture similarly identified 'economic farm units' as the goal, and in southern Rhodesia the Native Land Husbandry Act of 1951 was implemented in order to modernise and transform African agriculture, and create a class of 'progressive farmers' operating viable economic units (Duggan 1980).

Settlement schemes of different kinds were seen as one route to achieving such goals. Sometimes this involved a major reorganisation of patterns of settlement and land use in native reserves - such as following the Native Land Husbandry Act in southern Rhodesia, or 'betterment policies' in South Africa (Yawitch 1981). It also involved the creation of new settlements in areas where 'modern', 'progressive' agriculture could be practiced, as in the African Purchase Areas of southern Rhodesia (Cheater 1984), or irrigation-based resettlement schemes in Kenya (Metson 1979).

In southern Africa, a variety of institutions, such as departments of agricultural research and extension, were given the task of achieving the modernisation of agriculture. These institutions were profoundly influenced by the needs, aspirations and objectives of white settler farmers, an important political constituency for the colonial and apartheid state (Herbst, 1990). In the early period many settler farms did not conform to normative models of commercial farming derived from realities in the American mid-west or in East Anglia in Britain, but these ideal types formed key reference points for polices and programmes. Technical agricultural knowledge imported through colonial connections helped frame knowledge and practice in particular ways, and so came to shape how notions of viability were deployed.

In relation to peasant farmers living in so-called 'tribal' areas, recommendations to promote integrated, 'mixed farming', which became highly influential throughout the region, were based on models from 18th century England, as well as experiments undertaken in colonial northern Nigeria in the 1940 s (Scoones and Wolmer, 2002). Later, these kinds of technical imports were complemented by 'farm management' techniques and understandings of farming systems derived from mainstream agricultural economics, the classic texts and training models being imported largely from the United States. These understandings and techniques, often based on temperate zone agro-ecologies and production systems very different to those that were being developed in practice by farmers in southern Africa, became the standardized tools-of-the-trade for planning and implementing agricultural development. Departments of agricultural research and extension tended to replicate the organisational modes and priorities found in Europe or the US, and opportunities to challenge dominant framings and practices were extremely limited.

Despite numerous re-organisations and notional shifts in priorities after independence, the institutional and organisational infrastructure of African agriculture - though populated by different people, with a very different formal mandate and a vastly expanded target group, but often with a much depleted resource base - has remained remarkably consistent in its biases and assumptions. The continued dominance of an agricultural modernisation narrative is also evident in the design and priorities of such recent initiatives as the Comprehensive Africa Agricultural Development Programme and the Alliance for a Green Revolution in Africa ${ }^{4}$. These are influenced by the versions of agricultural development promoted by

4 http://www.nepad-caadp.net/ and http://www.agra-alliance.org/ 
globally powerful institutions such as the World Bank, whose World Development Report of 2008 emphasises the need to transform existing systems of production and move them towards a modernised, business-oriented, 'new' agriculture (World Bank 2007). These labels and categories carry with them assumptions about transformation, 'progress' and development trajectories that influence the specific policies advocated.

A core feature of the colonial period 5 was attempts by the state to develop a class of 'commercially viable small-holder farmers'. In southern Africa, however, these efforts were largely unsuccessful. Early peasant successes that threatened to compete with emerging white commercial farmers were snuffed out (Phimister 1988, Bundy 1979). For the most part the native reserves continued to function as areas supplying labour to dominant capitalist sectors such as mining and industry, as they were originally designed to do, with peasant agriculture providing a supplement to wages and remittances, and thus subsidizing low wage levels (Wolpe 1972, Palmer and Parsons 1977). Even strenuous efforts by the Rhodesian state to create a buffer class of small-scale commercial farmers, in the African Purchase Areas, made little impact on the overall agrarian structure. This remained starkly dualistic in character, with large-scale commercial farming at one pole and so-called 'subsistence farming' at the other (although the latter was always more productive than stereotypes of 'backward peasants' admit, as well as more socially differentiated). Rural poverty had its roots in both the dispossessions that helped create this dualism, and in the discriminatory manner in which the agricultural sector was managed. This was widely understood, with the 'land question' fuelling support for the liberation struggle in all three countries.

Inevitably, a key issue for newly elected democratic governments in Zimbabwe, Namibia and South Africa was whether or not to fundamentally alter agrarian structure through a largescale and rapid redistribution of productive land. For a variety of reasons, including doubts about the productive capacity of small-scale producers, this was deemed not feasible in any of the three countries. Instead, policies have set out to reform agrarian structure more gradually, through removing barriers to racial ownership and encouraging the de-racialisation of commercial farming, and through versions of market-based land reform. These policies have been premised on a particular view of viability and centred on preserving the productive capacity of the large-scale farming sector, while at same time promoting the growth of small-scale commercial farming, both in communal areas (the former reserves) and on redistributed land. A key consequence of this choice is the persistence of agrarian dualism, especially in South Africa and Namibia, and the revitalisation of colonial-era modernisation narratives, that see 'viable' small-scale farms as scaled-down versions of large-scale commercial farms. These narratives have proved remarkably resilient, and have continued to frame discourses on viability and the future of agriculture across the region.

Despite the centrality of the concept, ideas of economic viability are rarely defined with any clarity. As van den Brink et al (2007) point out, in former settler colonies the notion of viability generally derived from a specified income target, and viable farm sizes were calculated by first setting a target minimum income for white farmers, and then calculating the size of the farm. Rather than an objective, technical exercise, this was 'a social policy which ensured

5 In South Africa, the periods when the state pursued policies of segregation and apartheid. 
that white farmers earned an income acceptable to white society' (ibid: 170). This objective provided the rationale for legislation that restricted the subdivision of farms in South Africa, Namibia and Zimbabwe, and that remains in force in all three countries. According to Moyo (2007: 68), viability was always seen through the lenses of both race and class, Africans being seen to have lower requirements for 'subsistence' incomes than whites. It is clear that notions such as 'viability', despite their seemingly technical origins, carry within them multiple social and political meanings and implications. The tenacity of such concepts within policy discourses on land in the region is striking.

\section{Framing viability: frameworks for assessing land and agrarian reform}

While any term has its own location and history, it also must relate to a wider field of debate. What does the international literature on land and agrarian reform suggest is the appropriate way to assess viability? How do debates in southern Africa, informed by particular historical experiences, resonate with these? There are a number of competing analytical frameworks commonly used in assessments of land and agrarian reform (Table 1). The most important approaches are neo-classical economics, recent variants such as new institutional economics, livelihoods and welfarist approaches, and frameworks of analysis derived from Marxism and traditions of radical political economy. These approaches are associated, to varying degrees, with competing political ideologies and stances. Thus neo-classical economists are often associated with neo-liberal policy prescriptions; new institutional economists often articulate a form of agrarian populism or neo-populism; the sustainable livelihoods approach is associated with 'developmentalism' or 'welfarism', and Marxists and radical political economists emphasise the importance of class politics and popular mobilization and struggle. A primary influence in assessments of viability in redistributive land reform is the choice of analytical paradigm, whether or not this is explicitly acknowledged.

We briefly summarise and contrast these six frameworks in order to highlight the importance of intellectual paradigms and their associated theories and concepts in framing issues and problems. There is of course the risk of over-simplification and caricature, but our intention is to highlight distinctive features and their articulation with debates about viability, rather than offer any comprehensive review. Clearly there are many overlaps, nuances and grey areas, ones that we hint at but do not have the space to discuss in any depth. The benefits, we hope, of comparing and contrasting a wide range of perspectives will outweigh these limitations, as it is across these diverse conceptualizations of land and agrarian reform - and viability - that we believe a way forward must be found. In later sections of the paper we examine the degree to which these different frameworks - or sometimes blurred combinations of them - have framed and influenced viability debates in southern Africa, and with what consequences for policy and practice. 


\section{Neo-classical economics}

The central concerns of neo-classical economics are well-functioning markets and the Pareto-optimal efficiency outcomes that are achieved if market failures and distortions are minimised. Government planning and intervention are viewed as being accompanied by rentseeking behaviour, and therefore inefficiency. Key concepts in neo-classical theory include the notion of utility-maximising activities by individuals who produce commodities for selfconsumption or for sale, operating through a firm (or farm, in a rural setting), in order to maximise profit. Efficiency is evaluated by assessing factor productivity (i.e., the relative productivity of land, labour and capital).

The ideology associated with contemporary neo-classical orthodoxy is neo-liberalism, with its stress on getting the state out of markets (to reduce market 'distortions'), 'getting the prices right', and structural adjustment measures such as deregulation, currency devaluation, privatisation and fiscal austerity. The state's necessary role in providing public goods is recognized, as is the role of law in underpinning property rights and contracts. These reduce perceptions of risk and thus 'stimulate profit-maximising firms to invest, utility-maximising households to save, and hence economies to grow' (Lipton 1993: 642). This means that neoclassical economists are ambivalent about unequal distributions of property rights based on ascription (e.g. inheritance) rather than achievement, and hence about land reform, which can create the conditions for an optimal, cost-minimising, distribution of farm sizes (ibid: 642).

Byres (2006: 227-29) suggests that in the post-war period neo-classical development economists accepted that planning and state interventions, including land reform, were necessary in poor economies before the market could come into its own. Byres distinguishes this 'old' neo-classical economics from the strongly anti-state views that eventually came to dominate mainstream development economics from the 1970 s until the late 1990s, and is often tagged the Washington Consensus.

As Byres notes, in the Washington Consensus there was no place for land reform of any kind (ibid: 226) ${ }^{6}$. The beneficiaries of structural adjustment are seen to be efficient farmers at any scale, and this can include large-scale land owners engaged in production, with economies of scale relevant in relation to capital, farm machinery or chemical inputs. The declining role over time of the agricultural sector within a successfully developing economy is accepted as necessary and inevitable. Trade liberalization is seen as improving incentives to agriculture through the removal of protections for the urban, import-substituting sector, and agricultural price increases are expected, leading to a switch from subsistence to cash crops, improvements in agricultural productivity and output and hence the incomes of the rural poor (Deraniyagala and Fine 2006: 52-53).

In a neo-liberal perspective the growing role of agri-business in global agro-food regimes is viewed as an outcome of market-efficient processes based on the logic of comparative advantage, leading ultimately to socially optimal prices for both producers and consumers (Weis 2007: 119). The inconsistencies involved in wealthy OECD countries promoting struc-

6 See for example Lal (1983: 162-63). 
Table 1. Paradigms for assessing the 'viability' of redistributive land reform

\begin{tabular}{|c|c|c|c|c|c|c|}
\hline & $\begin{array}{l}\text { Neo-classical } \\
\text { economics }\end{array}$ & $\begin{array}{l}\text { New } \\
\text { institutional } \\
\text { economics }\end{array}$ & Livelihoods & Welfarism & $\begin{array}{l}\text { Radical political } \\
\text { economy }\end{array}$ & Marxism \\
\hline Central focus & $\begin{array}{l}\text { Well- } \\
\text { functioning } \\
\text { markets } \\
\text { vs market } \\
\text { distortions and } \\
\text { 'imperfections' }\end{array}$ & $\begin{array}{l}\text { Linking } \\
\text { equity and } \\
\text { productivity }\end{array}$ & $\begin{array}{l}\text { Development } \\
\text { as livelihood } \\
\text { improvement } \\
\text { and poverty } \\
\text { reduction }\end{array}$ & $\begin{array}{l}\text { Poverty } \\
\text { alleviation, } \\
\text { social } \\
\text { protection }\end{array}$ & $\begin{array}{l}\text { Development } \\
\text { as agrarian } \\
\text { transformation }\end{array}$ & $\begin{array}{l}\text { The Agrarian } \\
\text { Question, focusing } \\
\text { on the transition } \\
\text { to capitalism in } \\
\text { agriculture }\end{array}$ \\
\hline Key concepts & $\begin{array}{l}\text { Efficiency } \\
\text { in factor } \\
\text { productivity } \\
\text { (land, labour, } \\
\text { capital) }\end{array}$ & $\begin{array}{l}\text { Transaction } \\
\text { costs, } \\
\text { institutions, } \\
\text { the inverse } \\
\text { relationship }\end{array}$ & $\begin{array}{l}\text { Multiple } \\
\text { and diverse } \\
\text { livelihoods; de- } \\
\text { agrarianisation }\end{array}$ & $\begin{array}{l}\text { Household } \\
\text { food security; } \\
\text { vulnerability; } \\
\text { social } \\
\text { protection }\end{array}$ & $\begin{array}{l}\text { Peasants are } \\
\text { a social class } \\
\text { exploited by a } \\
\text { global corporate } \\
\text { food regime } \\
\text { Food sovereignty }\end{array}$ & $\begin{array}{l}\text { Social relations } \\
\text { of production, } \\
\text { property and power } \\
\text { (class); dynamics } \\
\text { of accumulation in } \\
\text { agriculture; }\end{array}$ \\
\hline $\begin{array}{l}\text { Land and } \\
\text { agric in } \\
\text { wider } \\
\text { context }\end{array}$ & $\begin{array}{l}\text { Declining } \\
\text { role of agric } \\
\text { in economy; } \\
\text { globalisation } \\
\text { of agro-food } \\
\text { markets is } \\
\text { positive in } \\
\text { lowering food } \\
\text { costs }\end{array}$ & $\begin{array}{l}\text { Unequal land } \\
\text { distribution } \\
\text { can constrain } \\
\text { economic } \\
\text { growth }\end{array}$ & $\begin{array}{l}\text { Key role of } \\
\text { agriculture in } \\
\text { kick-starting } \\
\text { growth; } \\
\text { globalisation } \\
\text { offers } \\
\text { opportunities } \\
\text { but often } \\
\text { negative for } \\
\text { the poor }\end{array}$ & $\begin{array}{l}\text { Small-scale } \\
\text { agriculture as } \\
\text { residual, as } \\
\text { safety net }\end{array}$ & $\begin{array}{l}\text { A global } \\
\text { corporate global } \\
\text { food regime } \\
\text { dispossesses } \\
\text { peasants via } \\
\text { market discipline } \\
\& \text { renders them } \\
\text { 'redundant' }\end{array}$ & $\begin{array}{l}\text { Links between } \\
\text { agricultural } \\
\text { development \& } \\
\text { industrialisation are } \\
\text { a key issue } \\
\text { Globalisation is } \\
\text { a key feature of } \\
\text { contemporary } \\
\text { capitalism }\end{array}$ \\
\hline Policies & $\begin{array}{l}\text { Market-led } \\
\text { land reform: } \\
\text { reduce market } \\
\text { imperfections; } \\
\text { register private } \\
\text { property rights; } \\
\text { provide credit } \\
\text { to promote } \\
\text { investment }\end{array}$ & $\begin{array}{l}\text { Market- } \\
\text { assisted land } \\
\text { reform: reduce } \\
\text { policy biases } \\
\text { favouring large } \\
\text { farms or urban } \\
\text { consumers; } \\
\text { promote } \\
\text { efficient } \\
\text { markets; } \\
\text { secure } \\
\text { property } \\
\text { rights; credit; } \\
\text { land taxes }\end{array}$ & $\begin{array}{l}\text { State action } \\
\text { to support } \\
\text { smallholder } \\
\text { production e.g. } \\
\text { land reform, } \\
\text { targeted } \\
\text { subsidies, co- } \\
\text { ordination of } \\
\text { marketing; }\end{array}$ & $\begin{array}{l}\text { Enhanced and } \\
\text { secure access } \\
\text { to land for } \\
\text { small-scale food } \\
\text { production as a } \\
\text { safety net }\end{array}$ & $\begin{array}{l}\text { Radical agrarian } \\
\text { reform that } \\
\text { secures rights } \\
\text { to land and } \\
\text { resources by } \\
\text { peasant farmers } \\
\text { Food sovereignty }\end{array}$ & $\begin{array}{l}\text { (a) Retain efficient } \\
\text { large capitalist } \\
\text { farms \& improve } \\
\text { conditions of } \\
\text { labour), or } \\
\text { (b) reforms } \\
\text { that promote } \\
\text { accumulation from } \\
\text { below, or (c) support } \\
\text { struggles for land by } \\
\text { exploited classes }\end{array}$ \\
\hline Beneficiaries & $\begin{array}{l}\text { Efficient } \\
\text { farmers at any } \\
\text { scale; (often } \\
\text { economies of } \\
\text { scale apply and } \\
\text { larger farms } \\
\text { seen as socially } \\
\text { efficient) }\end{array}$ & \begin{tabular}{|l|} 
Efficient small \\
farmers who \\
maximise \\
returns to land
\end{tabular} & $\begin{array}{l}\text { The rural poor } \\
\text { with multiple } \\
\text { livelihoods; } \\
\text { small farmers }\end{array}$ & $\begin{array}{l}\text { The rural } \\
\text { poor and } \\
\text { unemployed } \\
\text { with limited } \\
\text { access to jobs } \\
\text { or alternative } \\
\text { incomes }\end{array}$ & $\begin{array}{l}\text { Peasants (small } \\
\text { family farmers); } \\
\text { landless farm } \\
\text { workers; the } \\
\text { rural poor }\end{array}$ & $\begin{array}{l}\text { Landless workers, } \\
\text { semi-proletarians, } \\
\text { petty commodity } \\
\text { producers, emerging } \\
\text { capitalist farmers }\end{array}$ \\
\hline $\begin{array}{l}\text { Measures of } \\
\text { 'viability' }\end{array}$ & $\begin{array}{l}\text { Farm efficiency; } \\
\text { rates of return } \\
\text { on investment; } \\
\text { minimum } \\
\text { viable farm size }\end{array}$ & $\begin{array}{l}\text { Farm } \\
\text { efficiency; } \\
\text { distribution } \\
\text { of income; } \\
\text { poverty } \\
\text { impacts; } \\
\text { growth } \\
\text { multipliers }\end{array}$ & $\begin{array}{l}\text { Livelihood } \\
\text { impacts; } \\
\text { poverty } \\
\text { measures }\end{array}$ & $\begin{array}{l}\text { Levels of } \\
\text { household food } \\
\text { production } \\
\text { that make } \\
\text { efficient use } \\
\text { of household } \\
\text { resources }\end{array}$ & $\begin{array}{l}\text { Rurality, } \\
\text { agriculture \& } \\
\text { food are central } \\
\text { to social and } \\
\text { ecological } \\
\text { sustainability }\end{array}$ & $\begin{array}{l}\text { A function of } \\
\text { class relations and } \\
\text { dynamics } \\
\text { Agriculture's } \\
\text { contribution to } \\
\text { national economic } \\
\text { growth }\end{array}$ \\
\hline $\begin{array}{l}\text { Key } \\
\text { questions }\end{array}$ & $\begin{array}{l}\text { How efficient is } \\
\text { production on } \\
\text { redistributed } \\
\text { land? Returns } \\
\text { to land, labour, } \\
\text { capital? }\end{array}$ & $\begin{array}{l}\text { What factors } \\
\text { \& conditions } \\
\text { influence the } \\
\text { efficiency of } \\
\text { different scales } \\
\text { of production? }\end{array}$ & $\begin{array}{l}\text { What are } \\
\text { the multiple } \\
\text { sources of } \\
\text { livelihood for } \\
\text { land reform } \\
\text { beneficiaries? }\end{array}$ & $\begin{array}{l}\text { What difference } \\
\text { does food } \\
\text { production } \\
\text { make to } \\
\text { household } \\
\text { welfare of } \\
\text { land reform } \\
\text { beneficiaries? }\end{array}$ & $\begin{array}{l}\text { Does land reform } \\
\text { transform } \\
\text { exploitative } \\
\text { agrarian } \\
\text { structures and } \\
\text { food regimes? }\end{array}$ & $\begin{array}{l}\text { What dynamics of } \\
\text { class differentiation } \\
\text { and accumulation } \\
\text { occur within LR? }\end{array}$ \\
\hline
\end{tabular}


tural adjustment in the South, while simultaneously providing massive subsidies to their agricultural sectors and keeping in place protectionist tariffs on processed agricultural goods, is one reason why critics see neo-liberalism as ideology rather than respectable theory (ibid: 119).

In terms of neo-liberal ideology, then, viability must be assessed simply in terms of farm efficiency and the rate of return on investments in land and agriculture. Large farms and a declining rural population can be 'socially efficient', as can an agrarian structure dominated by large farms and global agri-business corporations. A viable land reform must promote market and business efficiency as its primary goal.

\section{New Institutional Economics}

For new institutional economists the neo-classical paradigm and its associated policy prescriptions are inadequate, and institutions assume a much more central role. In this view, while both peasants and large landowners are seen as rational decision-makers, real markets are often absent or 'thin' because of the existence of inadequate information or high transaction costs (such as the costs of supervising hired labour or enforcing contracts). To reduce the risks associated with imperfect information and high transaction costs, institutions such as rural money markets or sharecropping come into being. These can include interlocked markets, which are explicable as an 'endogenous' response to market imperfections. Property rights are seen as endogenous rural institutions that help reduce transaction costs (Lipton 1993: 641-42).

Power relations and structures are recognized as important in the new institutionalist paradigm, since groups or coalitions seek to use or alter their property rights and resources to their advantage (ibid: 641). Power structures, despite being 'endogenous', can thus lead to sub-optimal outcomes for society. For Lipton (ibid: 643), this is often the case when large land owners prevent land markets from optimizing farm size and allowing the economic strengths of labour-intensive, small-scale agriculture to be realized. Where an inverse relationship exists between farm size and output per hectare, the redistribution of land from large to small, family-operated holdings can 'accelerate and to some extent 'equalize' the (long-run endogenous) institutional outcomes of agricultural factor and product markets, technologies and power structures' (ibid: 642). Since highly unequal distributions of land can constrain economic growth, effective redistributive land reforms can make large contributions to development, as well as underpin industrial take-off (as in parts of East Asia).

To achieve these aims, Lipton (ibid: 642-43) argues that land reform must be market-oriented and 'incentive compatible', and aim to replace existing economic entities that perform endogenous economic functions (such as credit provision, security, technological innovation, processing, marketing, etc) with effective new institutional arrangements. It must also find a 'power compatible' path in order for it to be politically feasible. Both criteria are met by what he terms 'new wave' land reform, which should replace the state-led, landconfiscating approaches of the past that often involved the (forced) formation of inefficient collective or co-operative forms of production (ibid: 650-55). 
In this version of land reform the major beneficiaries should be efficient, small-scale farmers, who are enabled by appropriate rural development policies to maximise returns of land and contribute to rural non-farm economic growth. The key focus of viability assessment is farm efficiency, as well as overall economic efficiency ('general equilibrium effects'). Assessing the potential for growth multipliers and backwards and forwards linkages to farming is important too, because these help contribute to rural poverty reduction.

Lipton is a key exemplar of this type of new institutional economics thinking on land reform. The World Bank's 2003 policy research report on land, authored by Deininger, presents similar arguments in favour of 'new wave' land reform, but places greater emphasis on policies to secure land rights and promote land markets (and rental markets in particular) than on redistribution. The cornerstone of these arguments is once again the inverse relationship, arising most fundamentally from that fact that farms, worked by family members, do not incur the high supervision costs incurred by large farms hiring in labourers, and also have higher incentives to provide effort, giving the former a 'productivity advantage' and 'general superiority' (Deininger 2003: 81). However, imperfections in credit, input, product and insurance markets can overwhelm the inherent productivity advantages and give rise to a positive relationship between farm size and productivity leading to 'undesirable outcomes' (ibid: 82). State policies to reduce these imperfections and promote rental markets are recommended, with a strong emphasis on strengthening property rights and tenure security in order to facilitate long-term rental contracts.

For the World Bank redistributive land reform is required where 'the extremely unequal and often inefficient distribution of land ownership' is the result of 'power relationships and distortionary policies rather than market forces' (ibid: 143). Since market forces cannot be expected to lead to land redistribution 'at the rate that would be required to maximise efficiency and welfare outcomes', state interventions are required (ibid). Complementary policy instruments include secure land rights for beneficiaries, expropriation with compensation, progressive land taxation to increase the supply of underutilised land, divestiture of state land, foreclosure of mortgaged land, and promotion of rental and sales markets, decentralized implementation, training and technical assistance, and ensuring the rule of law (ibid: 155-56). Grants or loans should be provided 'on a scale that is sufficient to establish economically viable undertakings, while at the same time striving to accommodate a maximum number of beneficiaries' (ibid: 156).

New institutional economists thus assess viability in redistributive land reform in terms of three main criteria: productive efficiency, higher levels of equity and contributions by land reform to both wider economic growth and poverty reduction. Arguments along these lines were made in the Soviet Union in the 1920 s by the agrarian populist Chayanov, who advocated agricultural development on the basis of co-operative peasant households, organised as an independent class, and driven by the technical superiority of peasant household-based production systems (Chayanov 1966). Given their strong emphasis on peasants/small-scale farmers and the (mostly undifferentiated) rural poor, new institutional economists are sometimes seen as 'neo-populists' or 'neo-classical neo-populists' (Byres 2004). 


\section{Livelihoods}

A livelihoods perspective to development has influenced policy advocacy in relation to land reform, as well as the framing of many donor policies on land. The emphasis is mostly on reducing the vulnerability of the rural poor by securing their access to productive assets and resources (tenure reform), and sometimes reforms that result in greater equality in the distribution of land. Here land reform is strongly associated with mainstream developmentalism, as embodied in donor policy frameworks such as the Millennium Development Goals (DFID 2007).

A key concept in this approach is multiple and diverse livelihoods that combine a range of capabilities, assets and activities in order to off-set risks and cope with stresses and shocks such as drought, disease, and loss of employment (Chambers and Conway 1992). Another is the classification of material and social assets (including social relationships) into natural, human, social, physical and financial forms of 'capital' (Carney 1999). A third is the notion that livelihood strategies are institutionally and organisationally mediated, influencing the vulnerability or robustness of livelihood strategies. Land is a form of natural capital, access to which is mediated by institutions, such as land tenure, and policies (Scoones 1998, 2009).

The 'sustainable livelihoods framework' is seen by its proponents as providing explicit recognition that the livelihoods of the poor are complex and dynamic and combine formal and informal economic activity. The holistic and integrative aspects of the approach have made it appear attractive in comparison to approaches that focus more narrowly on production, employment and household income (Ellis 2000, Shackleton et al 2000). Criticisms of the livelihoods approach include its neglect of power relations (Murray 2002) and of structural inequalities rooted in class and gender relations and their complex interconnections $\left(\mathrm{O}^{\prime}\right.$ Laughlin 2004).

In rural economies land is seen as 'a basic livelihood asset, the principal form of natural capital from which people produce food and earn a living', and comprises cropland, grazing and common lands from which a range of natural resources can be harvested (Quan 2000: 32). Land also 'provides a supplementary source of livelihoods for rural workers and the urban poor' and 'as a heritable asset, land is the basis for the wealth and livelihood security of future rural generations' (ibid: 32 ). Caste and gender inequality in land access are problems that need to be addressed, as is the dampening effect of high levels of inequality on economic growth (DFID 2007: 1-2). Land reform may be required to secure equitable and efficient land use and promote pro-poor economic growth. Land can be used as collateral for loans, providing opportunities for investment and accumulation and encouraging the growth of business activity in general (ibid: 6).

Kydd et al (2000:18-19) agree that, while globalisation and liberalization are undermining the relative efficiency of small-scale farming, there are still grounds for supporting smallholder farming as a central feature of rural development, because it is multiplier-rich, accessible to the poor, and creates the basis for eventual 'good exits' from agriculture. Since it is 'unwise to automatically assume that settlement of previously large farms by small farms will lead to 'win-win' equity and efficiency gains' (ibid: 19), the case for redistribution must 
be made on an area by area basis. Kydd et al see potential for redistribution at the 'quite extensive' margins of large farms (ibid: 19), but also emphasise legislation to facilitate leasing of land and encouraging endogenous evolution of tenure systems towards clearly defined property rights. Government support will be crucial, and elite capture must be avoided, so that these policies do not 'erode the livelihoods of the poor and vulnerable' (ibid: 20).

Some analysts who use a livelihoods lens to examine agrarian change stress the de-agrarianisation of rural economies in recent years. Bryceson (2000) argues that livelihood systems in Africa have been profoundly transformed over the past two decades. Many households have diversified their livelihoods, shifted to non-agricultural income sources and individualized their economic activities. Bryceson questions whether agriculture should remain the core focus of development policy, but notes that 'African rural dwellers ... deeply value the pursuit of farming activities. Food self-provisioning is gaining in importance against a backdrop of food price inflation and proliferating cash needs' (ibid: 5). Rigg $(2006,196)$ notes the rapid diversification of rural livelihoods in the Asian contexts and suggests that 'sustainable livelihoods ... are increasingly likely to be divorced, spatially and occupationally from the land'. In his view policy should support people's efforts to leave farming, permitting the amalgamation of land holdings and the emergence of agrarian entrepreneurs.

In a livelihoods perspective, viability thus relates to a combination of assets, activities and social relationships that are robust and resilient, and which together reduce the vulnerability of poor households and individuals to shocks and stresses. Ecological sustainability is also stressed. However, in many livelihoods analyses an inherent tension is often revealed - between emphases on poverty alleviation via enhanced livelihoods of the poor (a form of welfarism), on the one hand, and on promoting economic growth and increased market access, on the other.

\section{Welfarism}

A welfarist emphasis on 'poverty alleviation', and a strong focus on household food security, is often proposed as a rationale for land reform. Tenure reform that secures access to land for food production and self-consumption is usually the main focus, but welfarist rationales for land redistribution are sometimes offered too. For example, the World Bank's 2003 report on land policies (Deininger 2003: 148) argues that 'access to relatively small amounts of land, in some cases not even owned land, can provide significant welfare benefits...'. The Bank's primary emphasis, however, as discussed above, is on 'productive efficiency' as a rationale for land redistribution, which should aim to maximise efficiency and welfare outcomes (ibid: 143).

Welfarism can take a variety of forms. In recent years there have been calls for agricultural development and 'livelihood promotion' in poor countries to be more explicitly linked to social protection policies and programmes, such as pensions and other forms of cash transfer, employment guarantee schemes and microfinance (Ellis et al 2009). Social protection measures could be designed to strengthen the resilience and reduce the vulnerability of poor households or individuals, and agriculture is inherently risky. But smallholder farmers in Asia and Africa are exposed to 'exceptional risks' (Farrington et al 2004, 2), many resulting from 
'over-hasty' privatisation of service-delivery or reductions in public investment, and market mechanisms are unlikely to deliver social protection. In relation to land, Farrington et al mention land redistribution only in passing, and identify various tenure reforms as important policy interventions: reform of tenancy arrangements, reform of inheritance laws that discriminate against women, improvements in documentation of freehold and leasehold rights so that land records can be used as collateral for loans, and enhancing poor people's security of access to common pool resources (ibid, 3).

Viability is thus defined in terms of the ability to protect poorer people from shocks and stress, the alleviation of poverty (according to a range of measures) and the reduction of vulnerability of those most at risk. While such definitions overlap with the concerns of those focused on livelihoods, here a viable land reform is aimed much more specifically at social protection and welfare goals.

\section{Radical political economy}

Radical political economy is very diverse, and here only one strand is discussed; that which tries to theorize contemporary forms of radical agrarian populism (McMichael 2008, Rosset et al 2006)7. Radical populists see rural poverty as the result of an unequal agrarian structure, and emphasise the oppression and exploitation of workers and peasants by powerful land-owning classes and agri-business interests. Unlike Marxists, however, class and other divisions amongst the rural poor receive less emphasis, and instead the convergence of the interests of groups who live on the land is stressed. Peasants are seen as under threat of dispossession by policies and actions that support an emerging global food regime dominated by large corporations. Since the mid-1990s, however, these threats to family-based farming have been resisted by resurgent peasant movements, including some that are transnational in scope. The leading example is Via Campesina, the 'peasant way', that advances the concept of food sovereignty as a radical alternative to conventional agricultural and food policies (Borras 2008). Implicit in this notion is a very different conception of viability.

Redistributive land reforms are seen as a key component of a broader agrarian reform that seeks to restructure class relations in the countryside (Rosset 2006). Agrarian reform includes a range of complementary policies alongside land redistribution, aimed at supporting peasant farmers and enhancing agricultural productivity, rural livelihoods and food sovereignty. Sometimes the inverse relationship and the contribution of equitable distributions of land to economic development more broadly, as in East Asia, are appealed to when arguing for radical land reform (Rosset 2006: 315-17).

Peasants as both beneficiaries and as agents of change are the main focus of contemporary rural radical populism, although social movements often suggest that agrarian reform should benefit other groupings as well ${ }^{8}$. The precise meaning of the term peasant, however,

7 Bernstein (2002) distinguishes between oppositional (anti-capitalist) and accommodationist (to neo-liberalism) varieties of neo-populism. We classify the former as radical populists.

8 A civil society statement issued at the International Conference on Agrarian Reform and Rural Development in 2006 calls for agrarian reform that will benefit 'communities of peasants, the landless, indigenous peoples, rural workers, fisherfolk, nomadic pastoralists, tribes, afro-descendents, ethnic minorities and displaced peoples, who base their work on the production of food and who maintain a relationship of respect and harmony with Mother Earth and the oceans' (cited in Borras 2008: 143). 
is often somewhat unclear. Borras (2008: 274) describes the heterogeneity of Via Campesina members, who include landless peasants and rural workers, small and part-time farmers in Western Europe, family farmers in the global South, middle to rich farmers in India, and the semi-proletariat in urban and peri-urban settings. These kinds of class-based differences between members, and the conflicts they might produce (for example, between the interests of small-scale capitalist farmers and the landless labourers they employ), tend to be ignored or down-played in radical populist analyses.

McMichael argues that contemporary peasant movements are reframing the classical agrarian question and formulating an alternative version of modernity. Mainstream development, it is argued, is complicit with neo-liberal globalisations and an international food regime overseen by the World Trade Organisation, is dominated by corporate interests from the North and leads to 'peasant redundancy' (McMichael 2008: 209). Peasant movements reject this ideology and trajectory, pointing to its disastrous effects on food production by small-scale farmers in the South. The global dominance of industrialised farming and agribusiness interests in the North, underpinned by rich country state subsidies, is fuelling cycles of dispossession in the South, and de-peasantisation is leading to the massive growth of a displaced, casual labour force, it is argued. In addition, such analysts argue, farming systems that rely heavily on artificial fertilizers, chemicals and fossil fuels are much less ecologically sustainable than the peasant systems that they are replacing.

Movements such as Via Campesina propose a notion of food sovereignty, 'the right of each nation to maintain and develop its own capacity to produce its basic foods, respecting cultural and productive diversity' (cited in McMichael, 2008: 210). Corporate agriculture entails securing the conditions for capitalist accumulation by lowering the cost of labour worldwide, and 'rules out a place for peasants, physically expelling them from the land, and epistemologically removing them from history' (ibid: 213). In contrast, the food sovereignty movement is grounded in 'a process of revaluing agriculture, rurality and food as essential to general social and ecological sustainability, beginning with a recharged peasantry' (ibid).

Conventional criteria for assessing viability in terms of efficiency and productivity, drawn from an economic logic that fetishises growth in quantitative terms, are rejected. These criteria externalize ecological effects such as chemical pollution, discount energy costs and subsidy structures for agri-business and undervalue the economic costs of agro-industrialisation (ibid: 214). While conventional criteria based on the 'spurious logic of monetary valuation's lead to small-scale agriculture being viewed as inefficient, food sovereignty emphasises the 'incommensurability of diverse agri- and food-cultures' and an 'agrarian identity based in a value complex weaving together ecological subjectivity and stewardship as a condition for social and environmental sustainability (ibid: 215).

For this strand of contemporary radical populism, viability in land reform thus means the ability of productive small-scale farming to secure peasant livelihoods, but also to promote 'broad-based and inclusive local, regional and national economic development, that benefits the majority of the population', as well as ecologically sustainable methods of farming (IPC for Food Sovereignty 2006, cited in Borras 2008, 144). Viability in this conception must

9 This phrase is drawn from Martinez-Alier (2002: 150), cited in McMichael 2008: 214. 
be assessed at a scale beyond the individual farm or land reform project, and seen in the context of a new agrarian order that embodies social justice, socio-economic transformation and ecological sustainability.

\section{Marxism}

Marxist analyses of land reform and agriculture are diverse and disagreements are common. They share a central focus on class relations, class structure and the dynamics of capital accumulation in agriculture. Key concepts include the social relations of production, the unequal distribution of property rights between classes, and class power (both economic and political). A key issue is the contribution of agriculture to capitalist accumulation and industrialisation more broadly (Akram-Lodhi and Kay 2009a, 5). This was a central concern in classical framings of the "agrarian question" in the late 19th and early 2oth centuries, and is debated today in the very different context of neo-liberal globalisation.

The 'classic' agrarian question is usefully summarised by Bernstein (2004, 198-200). In precapitalist societies the surplus labour of peasant producers is appropriated by landed property through rent. The transition to capitalism involves a process of primary accumulation that sees the formation of new agrarian classes (capitalist landed property, agrarian capital, and proletarian agricultural labour). The logic of capitalist social property relations establishes the conditions of market dependence, and drives the growth of agricultural productivity through technical innovation. If emergent industrial capital is strong enough to secure its interests, the enhanced agricultural surplus can be mobilized for industrial accumulation. Primary or primitive accumulation involves the dispossession of peasants, who are 'freed' to work in industry and other non-agricultural enterprises. Increased agricultural productivity helps lower the costs of reproducing the urban proletariat, contributing to capitalist accumulation in general.

Marxist analyses of the agrarian question focus on agrarian transitions in specific contexts. Resolution of the agrarian question can be achieved in variety of ways, including 'from above', as in the case of 19th century Prussia, where a land owning class metamorphosed into an agrarian capitalist class, or 'from below', where peasants differentiate themselves over time into classes of agrarian capital and agrarian labour (the 'American path'). To destroy the power of pre-capitalist landed property and ensure a successful transition to capitalism, a redistributive land reform, typically of the 'land to the tiller' variety, may be required. In this conception of the agrarian question '[o]nce pre-capitalist landed property - with its predatory appropriation of rent (vs. productive accumulation) - is destroyed .... there remains no rationale for redistributive land reform .... any notion of redistributive land reform that advocates the division of larger, more productive enterprises (capitalist and/or rich peasant farms) is ipso facto both reactionary and utopian'10 (Bernstein 2004: 199). It is utopian because it is unlikely to 'achieve its stated objective of 'efficiency and equity', of increasing agricultural productivity and rural employment and incomes on the basis of an egalitarian structure of 'family' farms' (ibid). Byres (2004) and Sender and Johnson (2004) are representative of this strand of Marxism"1.

10 Emphasis in original.

11 Sender and Johnston argue that in South Africa the redistribution of commercial farms to small farmers will have only negative effects on the employment and incomes of the rural poor, who will benefit most from poli- 
Bernstein (2004: 202) proposes another interpretation of the agrarian question: that in the contemporary world there is 'no longer an agrarian question of capital on a world scale, even when the agrarian question - as a basis of national accumulation and industrialisation - has not been resolved in many countries of the 'South"'12. He argues that a new agrarian question of labour has come into being, separated from its historic connection to that of capital, and manifested in struggles for land against various forms of capitalist landed property. This agrarian question is not centred on the development of the productive forces in agriculture, but on a crisis of the reproduction of increasingly fragmented classes of labour within a capitalist system unable to generate secure employment at a living wage for most people.

In Bernstein's conception 'classes of labour' include those engaged in unskilled wage labour, in insecure informal sector activities, in small-scale farming, and in various combinations of these, often linked across urban and rural sites and sectoral divides (ibid: 206). Peasants are best understood as petty commodity producers subject to processes of class differentiation: some succeed in becoming small rural capitalist farmers, some are able to reproduce themselves as small farmers, but others have to engage in wage labour or other forms of activity, such as micro-enterprises, to secure their livelihoods (Bernstein 2006, 454). Fragmentation and differentiation means that land struggles are 'likely to embody uneasy and erratic, contradictory and shifting, alliances of different class elements and tendencies' (ibid: 456).

Bernstein questions 'uncritical attachment to the benefits of large-scale farming' (ibid: 458), partly because the scale and distribution of capitalist property is often speculative rather than productive in character, and also because 'the productive superiority of large( $r$ )-scale farming is often contingent on conditions of profitability underwritten by direct and hidden subsidy and forms of economic and indeed ecological rent', as well as the environmental and social costs of modern capitalist arming systems. He is equally sceptical of 'small is beautiful' arguments, or indeed any models of 'virtuous farm scale' constructed on deductive grounds, and emphasises agriculture being able to provision the growing urban population of the world (ibid, 458).

Other Marxists are not of the view that the agrarian question of capital has now been resolved, or can be separated from the agrarian question of labour. Akram-Lodhi and Kay $(200 \mathrm{gb})$, for example, argue that the core of the agrarian question is the balance of class forces, nationally and internationally, between capital and labour. The balance of forces is contingent and variable, producing substantive diversity across different national and regional contexts, but the nature and trajectory of accumulation within (incomplete) transitions to capitalist agriculture remain a central issue in many parts of the world. They also argue that in an era of neo-liberal globalisation, the agrarian question has assumed new relevance, with food and agricultural production within global circuits of accumulation becoming of increasing concern to capital (ibid: 332), and massive levels of agro-food imports by China playing a key role within the global economy (ibid: 324).

cies that promote 'capitalist farming and the growth of decently remunerated agricultural wage employment' (Sender and Johnston 2004: 159)

12 Emphasis in original. 
Neo-liberal globalisation is extending the commodification of rural economies, and marketled concentration of land ownership is contributing to ongoing 'accumulation by dispossession' (of the rural poor). The increasing emphasis on agricultural exports as the motor of accumulation means that a key aspect of the agrarian question in countries of the South is now the nature and extent of linkages between the export-oriented sub-sector and the peasant production sub-sector. These linkages deeply influence the character of agrarian transitions under current conditions, and thus the capacity of a rural economy to enhance peasant livelihoods (ibid: 324-327).

From a Marxist perspective, then, viability in redistributive land reform is primarily a function of class relations and dynamics, and could refer to either successful accumulation by emerging classes of agrarian capital, either 'from above' or 'from below', or the reproduction of peasant farmers as petty commodity producers, or improved prospects for the livelihood security of differentiated classes of labour, for whom farming may be only one source of income. These are often mutually exclusive pathways, which means that answering the question 'viability for whom?' is likely to be politically contested. Another key criterion for Marxists, however, is the ability of growth in agriculture to contribute to national economic growth more broadly, which means that for society as a whole, viability must mean increasing productivity via reinvestment of a portion of surplus value.

\section{Viability in redistributive land reform in southern Africa}

How, then, have these frameworks framing viability in very different ways influenced the policy and practice of redistributive land reform in southern Africa over time? As we have seen, the way viability is defined has a major impact on the way land and agrarian reform is conceived and planned for.

The modernisation narratives discussed above, which focused on promoting an 'economically viable agriculture', have deeply influenced the framing of policies for redistributive land reform in South Africa, Zimbabwe and Namibia. But this has often been in a somewhat ambiguous manner. Indeed, a key feature of land reform debates in southern Africa is a pervasive disconnect between discourses centred on the politics of land reform, often involving heavy doses of populist and nationalist rhetoric, drawing on a variety of arguments with their roots in livelihoods perspectives, agrarian populism and Marxism, and the more technical discourses of economics, which stress pragmatic adjustments at the margins, and draw on variants of neo-classical and new institutional economics. Across the region, policy coherence has proved elusive to date (Lahiff 2003). In the following section we offer a brief review of some of the ways in which viability has figured in policy discourses in South Africa, Zimbabwe and Namibia, and explore the degree to which the different frameworks discussed above have influenced the way land and agrarian reform has been thought about and implemented ${ }^{13}$.

13 For more comprehensive country overviews, see papers by Lahiff (South Africa, Marongwe (Zimbabwe) and

Werner and Kruger (Namibia) on www.lalr.org.za. 


\section{South Africa}

The objectives and scope of post-apartheid land reform are set out clearly in the 1997 White Paper on South African Land Policy, summarising the goals of land reform as: 'to redress the injustices of apartheid; to foster national reconciliation and stability; to underpin economic growth; and to improve household welfare and alleviate poverty' (DLA 1997: v). A number of economic benefits are identified, including food security for the rural poor, and opportunities for expanded agricultural production by around 100,000 small-scale and subsistence farmers (ibid: 13). Land reform is said to be able to make a major contribution to reducing unemployment, given the potential of small, family-operated farms to generate more livelihoods on high potential arable land than larger farms and through the multiplier effect on the local economy. Implicit in these rationales is the view that small-scale forms of production offer many advantages over large-scale production.

A 'market-assisted' approach to land acquisition and transfer was adopted, based on voluntary transactions between willing sellers and willing buyers (ibid: 37 ). Grants were to be made available to applicants, and 'the poor and marginalized', as well as women, were targeted. Other criteria for prioritizing projects included the 'viability and sustainability of projects' defined in terms of economic and social viability of intended land use, fiscal sustainability by the local authority, environmental sustainability, proximity and access to markets and employment, and availability of water and infrastructure (ibid: 43). In framing the design of the programme a new institutional economics perspectives mixed uneasily with livelihoods and welfare priorities.

By the end of the 1990 progress in land redistribution was very slow, and a major problem was the lack of resources made available for post-transfer support to beneficiaries (Turner and Ibsen 2000). In addition, most redistribution projects involved groups of applicants pooling their government grants to purchase farms, as a consequence of the small size of the grant relative to farm size and the general reluctance of sellers and officials to sub-divide farms. Tensions and conflicts within large groups were common. In 1999 a review of the programme was commissioned, and a new policy framework called Land Redistribution for Agricultural Development (LRAD) was announced in 2000.

Under LRAD the previous focus on targeting land redistribution at the poor gave way to an emphasis on promoting black commercial farming, with a separate food security programme aimed at the poor ${ }^{14}$ (Jacobs 2003). Larger grants together with loan finance were offered to applicants, on a sliding scale, and an income ceiling was removed to encourage black entrepreneurs to apply. 'Commercial viability' now became a key criterion for approving the business plans required for all land reform projects. Agricultural support programmes for land reform beneficiaries were announced, to be implemented by provincial departments of agriculture, but these have been under-funded, poorly planned and ineffective to date (Lahiff 2008). According to Lahiff (2007b: 1589), 'the official emphasis on commercial 'viability' has increased considerably since the beginning of the land reform programme', and 'the 'commercial' logic of LRAD is now applied to all land reform applicants, regardless of their

14 The food security programme was never operationalised. 
resources, abilities, or stated objectives'. The key mechanism through which this commercial logic is applied is the business plan, which is usually drawn up by private consultants who have little contact with the intended beneficiaries:

Such plans typically provide ultra-optimistic projections for production and profit, based on textbook models drawn from the large scale commercial farming sector, and further influenced by the past use of the land in question. Production for the market is usually the only objective, and plans typically require substantial loans from commercial sources, purchase of heavy equipment, selection of crop varieties and livestock breeds previously unknown to the members, hiring of labour (despite typically high rates of unemployment amongst members themselves) and sometimes the employment of a professional farm manager to run the farm on behalf of the new owners...

A central weakness of most business plans is that they assume that the land will be operated as a single entity (i.e. as used by the previous owner), regardless of the size of the beneficiary group.... Because of the lack of support for subdivision, beneficiaries are often obliged to purchase properties much larger than they need, and even to expand the size of groups to aggregate sufficient grants to meet the purchase price. This results in widespread problems of group dynamics as former single-owner farms are turned into agricultural collectives.... (Lahiff 2007b, 158-89).

Outside of government, the language of viability dominates the discourse of a conservative alliance of landowners, agricultural economists and officials which is opposed to changes in agrarian structure, and argue instead for de-racialisation of landownership (ibid: 1589), and the establishment of 'viable and sustainable upcoming commercial farmers' (Doyer 2004: 8). This vision underpins the Strategic Plan for Agriculture agreed in 2001 between farmers' unions (representing white and black commercial farmers) and government. The strategic goal for the sector is 'to generate equitable access and participation in a globally competitive, profitable and sustainable agricultural sector contributing to a better life for all' (DoA 2001: 3). Enabling black South Africans to become successful in commercial farming and agribusiness requires 'well designed and targeted efforts to level the playing field and bring about a more representative and diverse sector' (ibid: 8). Land reform is identified as critically important for ensuring 'broad-based participation in the agricultural mainstream', not for altering agrarian structure.

Despite the new focus on commercial viability, high rates of failure in land reform continued to make headlines, and in 2005 a National Land Summit involving a wide range of stakeholders called for a fundamental review of land reform policy, including the willing seller, willing buyer principle. Following the Summit, the idea that land redistribution should be embedded within a wider agrarian reform focused on poverty reduction and that creates opportunities for smallholder farmers, became common in policy and public debates. However, there has been little clarity on what this might mean for beneficiary selection, programme design, post-transfer support and agricultural policy more generally (Lahiff 2008).

In 2007 the Department of Agriculture commissioned a study of 'minimum viable farm size' in different agro-ecological regions, to guide land reform planning (Aihoon et al 2007). This would provide 'an acceptable level of disposable household income' to a farmer and a dependent family (ibid: 7). The study recommended that the baseline should be a minimum household income of R4000/month (equivalent to the mean income of 'emerging consumers'), well above the official poverty line of $\mathrm{R}_{2275} /$ month. One rationale was that this target 
group would attract 'more competent small farmers than the more marginalized and less skilled communities' (ibid: 19). Adding premiums to compensate for risk and responsibility, and allowing for reinvestment of some income into the farming business, resulted in a targeted minimum net farm income of $\mathrm{R} 7400 /$ month. Farm sizes needed to provide such an income would vary by category of farming enterprise (based on extensive grazing, field cropping, horticulture, tree crops etc) and by agro-ecological region, the assumption being that the economics of commercial farming under current conditions would provide the basis for these calculations.

Such visions of viability echo the colonial discourses on modernisation, and are sometimes located in terms of a neo-liberal framing of land reform that emphasises business profitability. This view is expressed by private sector-funded think tanks such as the Centre for Development and Enterprise (CDE 2005, 2008), as well as organisations representing large-scale farmers. Given the legacies of colonial rule and apartheid, it is acknowledged by such groupings that the commercial farming sector has to be de-racialised, but the beneficiaries will be a few, relatively better-off black farmers and landowners, not the rural poor, because land reform 'is not the answer to rural poverty' (CDE 2005: 30).

Political debates on land policy, however, continue to be disconnected. For example, in the wide-ranging resolution adopted by the ruling African National Congress (ANC) at its 2007 national conference in Polokwane calls for an 'integrated programme of rural development and agrarian change', and for policies that support agriculture and labour-intensive forms of production in particular, expand the role and productivity of small-holder farming by the rural poor and land reform beneficiaries. It also resolves to restructure value chains and promote co-operatives, and review policies and laws that promote 'capital intensity and farm consolidation ... and that make it difficult to redistribute land to a modern and competitive smallholder sector' ${ }^{15}$. The 2009 ANC election manifesto promises that the ANC will 'intensify the land reform programme' and provide the rural poor with 'technical skills and financial resources to productively use the land to create sustainable livelihoods and decent work' ${ }^{\prime 16}$.

These statements could perhaps be read as suggesting that viability in land reform needs to be assessed in terms of a wider set of criteria than those derived from large-scale commercial farming, but what these might be is not spelled out. Meanwhile, in the South African context, the dominant technical framings centre not on a broader focus on agrarian restructuring, livelihoods and welfare issues, but on narrow business and target income criteria of viability.

\section{Zimbabwe}

In Zimbabwe land resettlement formed a major element of post-independence government policy. Ambitious targets were set in the early $1980 \mathrm{os}$, and a commitment to offer land to war veterans and the extremely poor. In Zimbabwe, welfarist goals for land reform have been combined with those that stress increased productivity and contributing to economic growth. The first post-independence resettlement programme set out to 'ameliorate the

15 See www.anc.og.za/ancdocs/history/conf/conference 52

16 See www.anc.org.za/ancdocs/manifestos.html 
plight of people adversely affected by the war and rehabilitate them', and to 'provide, at the lower end of the scale, opportunities for people who have no land and who are without employment, and may... be classed as destitute', as well as to 'extend and improve the base for productive agriculture in the peasant farming sector' (Government of Zimbabwe 1980, cited in Gonese and Mukora 2003: 175). The second phase of resettlement, initiated in the 1990s, included the objective of reducing 'the extent and intensity of poverty among rural families and farm workers'.

In the early period there were essentially two competing ideas about viability in land reform. First, there was the political imperative to address racially skewed patterns of land holding, within the constraints of the Lancaster House agreement. Providing land for former guerrilla fighters was a key part of the demobilisation process, and addressing extreme poverty in the communal areas formed part of a wider commitment by the new independent government to achieving food security for the poor and a more equitable pattern of development. Second, in parallel, and seemingly not in contradiction with the first imperative, was a technical version of agricultural viability, to be secured through farm planning and technical models.

Resettlement plans thus proposed a variety of different 'models'. These included Model A schemes, based on a planned village settlement and land use similar to that promoted in communal areas in earlier decades; Model B schemes, based on a socialist cooperative model; Model C out-grower schemes, linked to state farms; and Model D schemes, based on a village ranch model. In practice the village-based Model A dominated the resettlement landscape. This was a close replica of the vision for re-organised communal areas advocated by the influential American missionary and agricultural extension advisor, E.D. Alvord, in the 1930s (Alvord 1948). It involved separate grazing and arable areas in the context of a mixed farming system, a planned village settlement dividing the two, and full-time farmers engaged in productive and efficient smallholder agriculture, gaining the benefits of new technologies through state-supplied extension. For new settlers who complied with this vision, familiar livelihood strategies had to fundamentally alter, with links to kin and associated labour and draught sharing arrangements, key features in communal areas, disrupted. A prohibition on external employment reduced opportunities for remittance-sourced investment, and, given the wealth status of many new settlers, there were major capital constraints on the new farms. In this early period resettlement farming was circumscribed by this narrow view of viability.

Over the course of the 1980s, however, a number of shifts in thinking and practice occurred: each had implications for how viability was thought about. First, the strict planning and extension regime was difficult to maintain. Field-level agents realised that its strictures did not always make sense, and, at the margins at least, a certain amount of discretion was allowed (Alexander 1994: 334-35). Second, the early rush to do something about resettlement waned. Under the restrictive 'willing-seller, willing-buyer' conditions of the Lancaster House agreement, combined with the intensive planning and investment required to establish schemes, the programme was proving expensive. The pace of resettlement slowed and the ambitious targets set at 1980 were revised downwards. Third, with the slowing of the programme as a whole, the range of models of resettlement being promoted was narrowed essentially 
to the Model A schemes. Fourth, there was a significant shift in the process of selection of resettlement beneficiaries over time. While the initial settlers were indeed predominantly poorer (with fewer assets and less land in the communal areas), in the late 1980s asset-rich, skilled farmers became the main target group for resettlement. This was formalized in the government's 1990 Land Policy document (GoZ, 1990; see Moyo, 2000).

Through the 1980s these trends - and particularly the shift in resettlement beneficiaries - had a significant impact on how the 'viability' of resettlement was viewed. At the beginning, the programme was seen very much in social welfare terms, linked to a political commitment to redress inequality and reward liberation fighters. Except at election times, the programme was out of the political limelight and not seen as a major priority. Indeed, by the mid-1980s, the commercial farming sector was booming, with continued substantial support from the government, combined with a growing number of private initiatives geared to entry into new markets, including horticulture, floriculture, and wildlife. With less - or only sporadic - political interest, it was easy to hand the programme over to the technocrats.

The agricultural extension service, Agritex, was by now the main government agency involved. Tasked with providing technical advice to agriculture, with its previous history largely focused on the commercial sector, planning and extension took on a particular form. In extension manuals and training programmes, viability was defined in narrow, technical and economic terms and centred wholly on agricultural production, emphasising efficiency metrics drawing on neo-classical economics perspectives. The models used were based on farm management plans, rates of return and enterprise-specific budgets derived directly from the commercial sector. As the planners saw it, the drift of the land reform programme towards promoting the 'expansion of the communal areas' had to be stopped. If the resettlement programme was to mean anything, they argued, it must provide income and production for the nation, and be a model for small-scale, entrepreneurial commercial farming.

At the same time, the early 1990s saw major shifts in economic strategy in Zimbabwe, especially following adoption of the structural adjustment policy (ESAP) from 1991, pushed by an ideology of neo-liberalism by the International Financial institutions. An export-oriented, free-market agenda drove government policy, with redistributive land reform now seen as a marginal issue, one which was not going to deliver the economic growth and foreign exchange earning possibilities that a focus on the commercial agricultural sector would. This remained largely in white hands, and efforts to 'indigenize' commercial farming took centre stage. In this period, land acquired for the resettlement programme was often offered on long-term leases to well-connected, black business people, politicians and security force personnel (Alexander 1994, Moyo 2000,). With structural adjustment putting a major squeeze on government resources and donors being reluctant to support it, the pace of resettlement declined, with only 20,000 households being resettled between 1989 and 1996 (Moyo, 2000).

By the late 1990 s results began to emerge from the long-term monitoring of resettlement households (Kinsey 1999, Deininger et al 2000, Gunning et al 2000; Hoogeven and Kinsey 2001). Settler beneficiaries were reported as having higher incomes, lower income variability and more evenly distributed incomes (although higher childhood malnutrition) than their 
(near) equivalents in the communal areas (Kinsey 1999). Kinsey and colleagues argued that these (mostly) positive results emerged after a time lag, with an establishment phase where people organised themselves, gained access to services and accumulated productive assets (Kinsey 2003; Owens et al 2003). In sum, 'viability' had to be given a time dimension, and was not just the result of efficient production, but also about social organisation, institution building and coordinated post-settlement support. Emphasis thus extended to institutional and wider livelihoods perspectives, moving beyond the narrow neo-classical economics focus on commercial business models.

In this period, however, it was political processes, not empirical evaluation of performance and debates about different versions of viability, which put land reform back on the agenda. Land became central to a reassertion of the Mugabe government's populist/nationalist credentials (Moyo and Yeros 2005). In 1997, under the powers of the 1992 Land Acquisition Act, the government began a process of designation of 1471 commercial farms for compulsory purchase. As in the 1990 land policy, there were to be two main target groups: poor, landless people from communal areas, and entrepreneurial farmers (with college training or a Master Farmer certificate). A dual approach to resettlement was recognized - with welfare goals for the poor and landless and a production and business orientation for others. Implicit assumptions about 'viability' were evident: productive use meant making use of the whole farm, and direct involvement in farm management; there was a new emphasis on the entrepreneurial, small-scale commercial farmer. While there were social welfare objectives running in parallel, and quotas set for particular categories of people (female headed households, war veterans) highlight more populist social justice criteria, the main thrust reemphasised a commercial orientation for resettlement.

In 1998 the government presented the Phase II plan of the Land Reform and Resettlement Programme to a donor conference $(G o Z, 1998)$. This identified the slow pace of land reform as a problem, and the urgent need to scale up the programme. Land reform, it was claimed, would contribute to the economy by increasing the number of commercialized, small-scale farmers using formerly under-utilised land, and, through careful planning, would result in environmentally sustainable use. Such a policy, it was argued, would increase the conditions for sustainable peace and social stability by removing imbalances of land ownership in the country (GoZ, 1998). A series of model plans for resettlement were presented, including a village model $\left(A_{1}\right)$, a village ranch model, a self-contained small-scale commercial farming model (A2) and an irrigation scheme model. Technical designs embodied versions of viability, making a clear distinction between village-based systems, where production was for household food security (A1, again echoing Alvord's thinking in the 1930s), and commercial systems, where a business model of viability was assumed ( $A_{2}$, echoing the African Purchase Area, small-scale farming models of the 1950s).

Twenty years after Independence, land reform looked set to move forward with a vision of 'viability' once again firmly based on a dualistic system of agriculture, with commercial profitability and economic returns the central metrics of success. But it was not to be, as a new political dynamic took hold. An announcement by the government in late 1998 that two million hectares of land were to be acquired upset the careful balance achieved only months before. From 1999, in the midst of political confusion and intense debate generated by a Constitution- 
al referendum and in the run-up to the 2000 national elections, land invasions started across the country. Sometimes these were spontaneous efforts involving only local people, sometimes they were organised by networks of war veterans, and sometimes they involved the government and security forces. (Chaumba et al 2003, Marongwe 2009, Moyo and Yeros 2005) In parallel to the government's objectives, based on the commercial viability of the smallholder sector, other visions of the resettlement programme soon emerged - including claims for restitution of 'ancestral lands', compensation for war veterans, and wider social and equity goals linked to a radical political economy argument for the restructuring of the agrarian economy. Each suggested in turn different framings of viability, and the neat if uneasy consensus struck around a commercially-driven smallholder sector, linked to a reduced, but still significant, large-scale commercial farm sector, rapidly unravelled. The hastily concocted 'Fast Track Programme' confirmed elements of the earlier plans, including the distinction between $A_{1}$ and $A_{2}$ models, as well as maximum farm sizes by type of farm and agro-ecological region (GoZ, 2001). Large targets for land acquisition were set - initially five million hectares - and were then significantly exceeded as land invasions continued. 'Beneficiary selection' no longer focused particularly on skilled, well-resourced entrepreneurial farmers, but responded to local circumstance, sometimes involving political pressure to offer poorer people land as well as the manoeuvring of elite interests (UNDP, 2002; PLRC, 2003; Sachikonye, 2003; Masiiwa, 2004; Marongwe, 2003, Marongwe 2009).

The result has been a tense to-and-fro between the technocrats who have tried to reassert their authority and the politicians, who have continued to use the offer of new land as a form of patronage (Fontein, 2005). Thus technical definitions of viability - in terms of farm size, land use and business plans - rubbed up against political expediency and processes of local political accommodation. Thus, in any area today, some so-called $A_{1}$ farms are larger than some $A_{2}$ farms, with significant numbers of both $A_{1}$ and $A_{2}$ farms being smaller than what was deemed the 'viable' economic size for that particular natural region, as more people were squeezed in. In many places, disputes and uncertainties persist about the status of new settlements, with some areas still being 'informal', having been settled spontaneously during the invasion period with a wide variety of settlement and land use patterns. And alongside this variety of smallholdings, very large farms do still persist, sometimes held by former owners and sometimes having been taken over by a politically well-connected 'new' farmer.

Fast-track land reform has resulted in extreme diversity, certainly at a national level, but also within districts and provinces, and even on single former farms. The debate about 'viability' in Zimbabwe today therefore is particularly complex and much more contested than elsewhere in the region. At the level of formal policy there remains a distinction between a household food security oriented objective (for $A_{1}$ ) and a business-oriented, commercial objective (for $A_{2}$ ), reflecting a mix of livelihood and welfarist perspectives and neo-classical and new institutional economics perspectives respectively. Dualism remains a strong feature of official thinking about the agrarian economy, but the variations within and across these models is such that neat distinctions do not mean much in practice. As people establish themselves on the new farms a large range of trajectories are evident - and with this multiple versions of viability. Different people, with different assets, different connections and 
different ambitions are able to do very different things with the land. What happens on new land gained under the Fast-Track Programme is highly dependent on wider livelihood portfolios of individuals and households, as well as social, economic and political connections. Constructions of viability therefore vary significantly within the new resettlements, and may not tally with those in the minds of the technocrats and planners. Zimbabwean experience thus suggests that a fundamental rethink of definitions and framings of success and viability is required in land redistribution settings.

\section{Namibia}

Namibia is somewhat different from South Africa and Zimbabwe, in that white settlers took possession of land that was mostly semi-arid in nature and suitable for livestock production rather than cropping. As a result it was relatively sparsely populated. People living in more densely settled areas with higher rainfall and thus suitable for cropping, found in the north of the country, were generally not dispossessed. White farmers established a commercial farming sector based largely on extensive livestock ranching, with farm size averaging between 5000 and 6000 hectares. Land redistribution is focused on these large ranches (Werner and Kruger 2007: 6).

Before independence in 1990, SWAPO thinking on land reform 'was essentially pragmatic' and its approach was modelled in part on the approach being followed by Zimbabwe in the 1980s, in relation to both methods of land acquisition and resettlement models (ibid: 6). In SWAPO's view farms in the semi-arid south of the country needed to be kept 'viable and efficient' (ibid: 6). After independence, according to Tapscott (1995: 165), the most vocal claims for land redistribution came from wealthier black farmers wanting to increase their access to land. A national conference on land reform in 1991 tried to find a balance between concerns for addressing colonial dispossession, equity and efficiency. It resolved to base decisions on the redistribution of freehold land on 'scientific data' on issues such as the extent of under-utilised land, multiple ownership of farms, and 'viable farm sizes' (Werner and Kruger 2007: 9).

A land redistribution policy framework was adopted in which government purchases large scale commercial farms on from willing sellers, sub-divides the farms and allocates the new units to small-scale farmers. The objectives are to redress past imbalances, provide opportunities for food self-sufficiency, create employment in full-time farming, 'bring smallholder farmers into the mainstream of the Namibian economy by producing for the market', alleviate population pressure in communal areas, and allow those displaced by the war of liberation to re-integrate into society. Previously disadvantaged Namibians are specified as the targeted beneficiaries (RoN 2001: 3).

The main resettlement model that has been pursued is the Farm Unit Resettlement Scheme (FURS), in which individual beneficiaries owning not more than 150 large stock units are allocated a 'small' farm (notionally at least 1500 ha in extent in the north, and 3000 ha in the south) ${ }^{17}$ and enter into a long term lease agreement with government (Werner and Kruger

17 In practice, average resettlement farm sizes have been smaller than these targets:1200 ha in the north and 2138

ha in the south (Werner and Kruger 2007: 13).. 
2007: 13). A small number of group schemes for unemployed farm workers and very poor people have also been implemented, mainly adjacent to communal areas in the north where cropping is feasible. In addition to resettlement, an Affirmative Action Loan Scheme (AALS) provides subsidies for purchase of commercial farms by black Namibians, with the objective of encouraging large herd owners from communal areas to 'become fully-fledged commercial farmers' (ibid: 14). By 2005 a total of 625 farms had been acquired through AALS, compared to 163 under FURS, or almost four times as many. Around 85 percent of freehold land remained in the ownership of whites (ibid: 17).

Although policy documents have occasionally voiced concerns that land reform was not doing enough to address poverty, government planning targets continue to be low. For example, only 36 families per annum were to be resettled under FURS between 2001 and 2006, compared to official estimates that 243000 people were 'unemployed, homeless and landless' and eligible for resettlement (ibid: 20).

The majority of FURS beneficiaries earn most of their income off-farm from jobs or businesses, many are employed in low-level clerical jobs in government, and less than a third regard farming as their main occupation. One study concluded that they are can be classified as 'lower-middle income households' (ibid: 21). Some studies suggest that the major farming problems facing beneficiaries have been inadequate capital to build livestock herd size to the point where the grazing resources of the farm are fully utilised, and lack of sufficient water points (Schuh et al 2006, cited in Werner and Kruger 2007: 23). Another study found that gross margins per annum from livestock sales in 2003 were around N\$ 6 799, compared to a 'decent living income' for Namibia estimated by the National Planning Commission at N\$ 15000 per annum for a household of five (PTT 2005: 50, cited in Werner and Kruger 2007: 24). Lack of post-settlement technical support, especially in relation to management skills, has been commonly identified as a major problem.

Few data on AALS beneficiaries are available, but Sherbourne (2004: 16) suggests that the evidence on hand suggests that most are part-time rather than full-time farmers. Many appear to be finding it difficult to repay their loans, in part due to the fact that land prices are much higher than the productive value of the land, and many have had to sell livestock to service loans at the expense of building up herd size (Werner and Kruger 2007: 25).

A notion of 'economically viable farm size' has been central to debates about land redistribution in Namibia, the key reference point being the profitability of commercial livestock ranching. The National Land Policy states that subdivision of large farms should be conditional on the 'maintenance of farming units of an economically viable size' (RoN 1998: 16, cited in Werner and Kruger 2007: 22). Government's Permanent Technical Team on Land Reform has suggested that 'there is a cut-off point below which a piece of land cannot be farmed on economically viable basis', but 'any size above this absolute minimum depends on the income expectations people have' (PTT 2005: 22, cited in Werner and Kruger 2007: 22). The Ministry of Lands, Resettlement and Rehabilitation has accepted a target income of N\$15 000 per annum for a household of five. 
Other studies suggest that small-scale cattle farmers on 1000 ha could earn gross margins of around N\$27000 per annum, and sheep farmers on 3000 ha in the arid southern regions could generate a gross margin of $\mathrm{N} \$ 99000$ per annum. However, these potential incomes assumed that beneficiaries owned sufficient livestock, or had access to sufficient off-farm income to finance herd build-up, and had experience of managing medium-scale farming enterprises (GFA 2003: 14, cited in Werner and Kruger 2007: 23), and it appears that few, if any, beneficiaries, meet these criteria . In contrast, the Namibia Agriculture Union argues that farming is a business and that the yardstick for viability should be 'medium enterprises' with a turnover of $\mathrm{N} \$ 1$ million per annum, no more than ten employees and no less than 500 large stock units. This would require farm sizes ranging from 5000 to 8000 ha (NAU 2005: 54, cited in Werner and Kruger 2007: 22).

Werner argues that current models of resettlement do not accommodate the poor, and that alternative modes of land utilisation need to be developed, such as range management areas used by groups organised into grazing associations, or even the expansion of communal areas (Werner and Kruger 2007: 31). This implies rather different interpretations of viability than those that currently dominate policy thinking, which are all based on scaled-down versions of commercial ranching.

\section{Rethinking viability in southern African land reform}

As the previous sections have shown, debates about viability and land reform in South Africa, Zimbabwe and Namibia involve contested, overlapping and sometimes contradictory visions of viability. The result is often extreme policy incoherence and conflict, with no clear vision for the way forward. There is of course no easy resolution of contested visions of land reform, and a substantial and informed deliberation on alternatives and combinations is clearly needed. How to go about this? What are the questions that must be asked? What might a more integrated, holistic approach look like? This final section of the paper explores which elements of the different frameworks introduced earlier might help in providing a more coherent and effective way of thinking about viability, in turn defining the 'success' of redistributive land reform in more meaningful ways. By focusing on the key questions posed for each framework at the bottom of Table 1, a set of ways of thinking about viability for the southern African context are offered.

For example, from the neo-classical economics perspective, the key question is: how efficient is production on redistributed land? A concern with productive efficiency is clearly important: policies that promote the optimal use of scarce land, labour and capital are important, while not accepting a simplistic emphasis on 'market forces' as the driver of wealth creation. From the new institutional economics perspective, the key question is: what factors and conditions influence the efficiency of different scales of production? Questions of scale of production are key in the southern African context, and so a focus on factors (including institutions and policies) that influence the efficiency of a variety of forms and scales of produc- 
tion is important, while not accepting the neo-institutionalist premise of a pervasive inverse relationship between scale and efficiency. From a livelihoods perspective, the key question is: what are the multiple sources of livelihood for land reform beneficiaries? In southern Africa, a focus on the multiple livelihood sources of poor people would help avoid an overlynarrow focus on farming alone, while not being blind to the structural roots of poverty. From a welfarist approach, the key question is: what difference does food production make to household welfare of land reform beneficiaries? The potential impacts of land redistribution on household food security and vulnerability are significant in southern Africa, without accepting the view that this should be the main purpose of land reform.

From contemporary radical populist perspectives, the key question is: does land reform transform exploitative agrarian structures and food regimes? In the southern African setting, one might therefore take on board a central concern with the need to reconfigure food production regimes and associated agrarian structures (at both the national and international scale), including the distribution of productive enterprises and associated property rights, and their performance in terms of output and net income, while not accepting an over-emphasis on the common interests of 'peasants' or 'the rural poor'. Finally, from the Marxist tradition the key question is: what dynamics of class differentiation and accumulation occur within land reform? A central concern with evaluating the economics of land reform in terms of a wider concept of social efficiency and the contribution of agriculture to the growth of society's productive capacities would be an important contribution in the southern African context. This would combine with a focus on the class and gender relations that underpin the organisation of production and of agrarian structure, while not accepting the idealization of large-scale farming in some strands of the tradition, or an overly-narrow focus on class dynamics to the exclusion of other relevant factors.

Derived from our earlier analysis of experiences from southern Africa - but also a reflection on underlying analytical paradigms - we suggest that each of the above questions must be posed in tandem in any assessment of the viability - or success - of land redistribution or agrarian reform. This would help shift the debate about viability away from the narrow, technocratic economism which has dominated the way such issues have been viewed in southern Africa and beyond. Too often this has been allied to strong normative assumptions, hooked into a long history of the assumed benefits of a dualistic agrarian system where modern, large-scale agriculture is seen as the ideal.

We suggest that a more textured and variegated approach to assessing viability, rooted in diverse conceptual frameworks, can provide a more effective - and ultimately more rigorous - approach to the assessment of redistributive land reform. Using the key questions highlighted in Table 1 and discussed above, Table 2 offers a set of assessment approaches that could be used to explore these themes, redefining viability - and associated measures of success - in new ways. Each offers a different lens on the questions surrounding 'viability', drawing on different conceptual frameworks, with different foci and scales. Taken together, we argue, these provide a more comprehensive approach to assessing land and agrarian reform. 
Table 2: Assessing land reform and framing viability: six key questions

\begin{tabular}{|c|c|}
\hline Conceptual framework and key question & $\begin{array}{l}\text { Approaches to assessing land reform - and } \\
\text { framing viability }\end{array}$ \\
\hline $\begin{array}{l}\text { Neo-classical economics: How efficient is } \\
\text { production on redistributed land? }\end{array}$ & $\begin{array}{l}\text { Returns to land, labour and capital across different } \\
\text { farm sizes. Focus on production efficiency - and } \\
\text { farm scale. }\end{array}$ \\
\hline $\begin{array}{l}\text { New institutional economics: What factors and } \\
\text { conditions influence the efficiency of different } \\
\text { scales of production? }\end{array}$ & $\begin{array}{l}\text { Transaction costs (e.g. labour supervision) and } \\
\text { institutional factors (e.g. market functioning) } \\
\text { affecting production in land reform areas. Non- } \\
\text { market interventions to improve efficiency } \\
\text { through coordination. Focus on institutional } \\
\text { conditions - and programme-level scales. }\end{array}$ \\
\hline $\begin{array}{l}\text { Livelihoods perspectives: What are the multiple } \\
\text { sources of livelihood for land reform beneficiaries? }\end{array}$ & $\begin{array}{l}\text { Multiple livelihood portfolios, with land } \\
\text { access contributing to overall sustainability of } \\
\text { diverse and differentiated livelihoods. Focus on } \\
\text { livelihoods and local economic linkages - and } \\
\text { household, community and regional economic } \\
\text { scales. }\end{array}$ \\
\hline $\begin{array}{l}\text { Welfarist approaches: What difference does food } \\
\text { production make to household welfare of land } \\
\text { reform beneficiaries? }\end{array}$ & $\begin{array}{l}\text { Role of land - and agricultural production derived } \\
\text { from it - as a source of social protection, and } \\
\text { a buffer against shocks and stresses. Focus on } \\
\text { vulnerability - and individual and household scale. }\end{array}$ \\
\hline $\begin{array}{l}\text { Radical political economy: Does land reform } \\
\text { transform exploitative agrarian structures and } \\
\text { food regimes? }\end{array}$ & $\begin{array}{l}\text { Changes in agrarian structure, and the position } \\
\text { of and relationships between peasants, workers } \\
\text { and large-scale farmers - and the wider agrarian } \\
\text { economy. Focus on political economy and (food) } \\
\text { sovereignty - and regional scales. }\end{array}$ \\
\hline $\begin{array}{l}\text { Marxism: What dynamics of class differentiation } \\
\text { and accumulation occur within land reform? }\end{array}$ & $\begin{array}{l}\text { Patterns of accumulation (and decline, } \\
\text { dispossession) across different classes - and } \\
\text { genders - in land reform settings - and the } \\
\text { impacts on wider economic growth and class } \\
\text { structure. Focus on class - and broader scales. }\end{array}$ \\
\hline
\end{tabular}

\section{Conclusion}

A central challenge - certainly for southern Africa, but also beyond - lies in embracing a new approach to assessing land reform, and thus to understanding viability and success. This must go beyond the narrow technical view that currently holds much debate on land reform in southern Africa in its iron grip. As we have seen, the dominant approach is strongly influenced by project appraisal and farm management techniques developed for the large-scale commercial farming sector, is powerfully informed by ideas about efficiency derived from neo-classical economics, and is rooted in the dominance of a particular type of commercial farming within a highly dualistic agrarian structure. This paper argues that alternative perspectives, from diverse theoretical and political traditions, help to expand and enrich the debate.

The implications are several. One is that an expanded and more diverse set of measures of viability than those used in the past is required, which in turn requires new methodologies for the collection and analysis of data. A more plural, holistic and integrated set of methods will acknowledge the tensions and trade-offs between different pathways of agrarian change 
- and so also of different framings of viability and success. A second implication is that analysts and policy makers should be encouraged to make explicit their framing assumptions, underlying values and larger policy goals when assessing or advocating alternative policy options for redistributive land reform. This will help to locate their assessments and choices within the framework of competing paradigms and approaches, and facilitate consideration of coherence and consistency. Finally, bringing a wider array of perspectives into the picture, and making explicit the different assumptions, political orientation and methodologies for assessment implied by each, could contribute to a more effective and coherent public debate about land reform policies. In southern Africa, in particular, this is urgently needed.

\section{References}

Aihoon, K. M. Cherry and E. Kassier. 2007. Determination of the minimum viable farm size. Discussion Paper, Department of Agriculture, Pretoria.

Akram-Lodhi, A.H. and C. Kay. 2009a. The agrarian question. Peasants and rural change. In: A.H. AkramLodhi and C. Kay, eds, Peasants and Globalization. Political economy, rural transformation and the agrarian question. London and New York: Routledge, pp. 3-34.

Akram-Lodhi, A.H. and C. Kay. 200gb. Neoliberal globalization, the traits of rural accumulation and rural politics. The agrarian question in the twenty-first century. In: A.H. Akram-Lodhi and C. Kay, eds, Peasants and Globalization. Political economy, rural transformation and the agrarian question. London and New York: Routledge, pp. 315-38.

Alexander, J.1994. State, peasantry and resettlement in Zimbabwe. Review of African Political Economy, 61, 325-345.

Alvord, E.D.1948. The progress of Native Agriculture in Southern Rhodesia. The New Rhodesia 15,18-19.

Bernstein, H. 2004. 'Changing Before Our Very Eyes': Agrarian Questions and the Politics of Land in Capitalism Today. Journal of Agrarian Change, 4(1, 2), 190-225.

Bernstein H. 2006. Is There an Agrarian Question in the $21^{\text {st }}$ Century? Canadian Journal of Development Studies, XXVII(4), 449-6o.

Borras, S. 2008. La Via Campesina and its Global Campaign for Agrarian Reform. Journal of Agrarian Change, 8(2, 3), 258-89.

Borras, S., M. Edelman and C. Kay. 2008. Transnational Agrarian Movements. Origins and Politics, Campaigns and Impacts, Journal of Agrarian Change, 8 (2, 3), 169-204.

Bryceson, D. 2000. African Peasants' Centrality and Marginality: Rural Labour Transformations. In: D. Bryceson, C. Kay and J. Mooij, eds. Disappearing Peasantries? Rural Labour in Africa, Asia and Latin America. London: Intermediate Publications, pp. 37-63.

Bundy, C. 1979. The Rise and Fall of the South African Peasantry. London: Heinemann.

Byres, T.J. 2004. Neo-Classical Neo-Populism 25 Years On: Déjà vu and Deja Passe. Towards A Critique. Journal of Agrarian Change 4(1, 2), 17-44.

Byres, T.J. 2006. Agriculture and Development: Towards a Critique of the 'New Neoclassical Development Economics' and of 'Neoclassical Neo-populism'. In: Jomo K.S. and Ben Fine, eds. The New Development Economics. After the Washington Consensus. Delhi, London and New York: Tulika Books and Zed Books, pp. 222-48. 
Carney, D., ed. 1998. Sustainable Rural Livelihoods: What Contributions Can We Make? London: Department for International Development.

Centre for Development and Enterprise. 2005. Land Reform in South Africa: a $21^{\text {st }}$ century perspective. Research Report No. 14. Johannesburg: Centre for Development and Enterprise.

Centre for Development and Enterprise. 2008. Land Reform in South Africa. Getting back on track. Research Report No. 16. Johannesburg: Centre for Development and Enterprise.

Chambers, R. and G. Conway. 1992. Sustainable Rural Livelihoods: Practical Concepts for the $21^{\text {st }}$ century. IDS Discussion Paper, 296. Brighton: Institute for Development Studies.

Chaumba, J., I. Scoones, 2003. From jambanja to planning: the reassertion of technocracy inland reform in south-eastern Zimbabwe? Journal of Modern African Studies, 41(4), 533-54.

Chayanov, A. V. (1986) The Theory of Peasant Economy, Madison, WI, The University of Wisconsin Press.

Cheater, A. 1984. Idioms of Accumulation. Gweru: Mambo Press.

Deraniyagala, S. and B. Fine. 2006. Kicking Away the Logic: Free Trade is Neither the Question Nor the Answer for Development. In: Jomo K.S. and Ben Fine, eds. The New Development Economics. After the Washington Consensus. Delhi, London and New York: Tulika Books and Zed Books, pp. 46-67.

Deininger, K. 2003. Land policies for growth and poverty reduction. Washington, DC and Oxford: World Bank and Oxford University Press.

Deininger K., H. Hoogeven and B. Kinsey. 2000. Productivity and Equity Impacts of Land Reform: the Case of Zimbabwe. Paper presented at the mini-symposium on Improving Land Access and Asset Ownership by the Poor through Land Reform: empirical evidence and policy implications. At the XXIV International Conference of Agricultural Economics, August 13-18 200, Berlin, Germany.

Department for International Development. 2007. Land. Better access and secure rights for poor people. London: Department for International Development, UK.

Department of Agriculture. 2001. The Strategic Plan for South African Agriculture. Pretoria: Department of Agriculture.

Department of Land Affairs. 1997. White Paper on South African Land Policy. Pretoria: Department of Land Affairs.

Doyer, T. 2004. BEE: a call for calm. Farmer's Weekly, 13 August 2004: 8.

Duggan, W. 1980. The Native Land Husbandry Act of 1951 and the rural African middle class of Southern Rhodesia. African Affairs, LXXIX: 227-39.

Ellis, F. 2000. Rural Livelihoods and Diversity in Developing Countries. Oxford: Oxford University Press.

Ellis F. and S. Biggs. 2001. Evolving Themes in Rural Development, 1950s-200os. Development Policy, 19(4), 437-48.

Ellis, F., S. Devereaux and P. White. 2009. Social Protection in Africa. Cheltenham: Edward Elgar.

Farrington, J., R. Slater and R. Holmes. 2004. Social Protection and Pro-poor Agricultural Growth: What Scope for Synergies? Natural Resource Perspectives, No. 91. London: Overseas Development Institute.

Fontein, J. 2005. Reclaiming Zimbabwe's Unfinished Business: Review Article. Africa 75(4), 599-605.

GFA terra systems GmbH. 2003. Namibia Screening Mission: Infrastructure support for land reform programme in Namibia. Final Report. Hamburg: GFA.

Gonese, F. and C. Mukora. 2003. Beneficiary selection, infrastructure provision and beneficiary support. In: M. Roth and F. Gonese (eds.). Delivering land and securing rural livelihoods: Post-independence land reform and resettlement in Zimbabwe. Harare and Madison, Centre for Applied Social Sciences, University of Zimbabwe, and Land Tenure Center, University of Wisconsin-Madison. 
Government of Zimbabwe. 1980. Resettlement Policies and Procedures. Harare: Government of Zimbabwe.

Government of Zimbabwe.1998. Land Reform and Resettlement Programme, Phase II. Harare: Government of Zimbabwe.

Government of Zimbabwe. 2001. Land Reform and Resettlement Programme, Revised Phase II. Harare: Government of Zimbabwe.

Gunning, J., J. Hoddinott, B. Kinsey and T. Owens. 2000. Revisiting Forever Gained: Income Dynamics in the Resettlement Areas of Zimbabwe, 1983-96. Journal of Development Studies, 36(6), 131-54.

Hoogeveen, J. G. M. and B. H. Kinsey. 2001. Land Reform, Growth and Equity: Emerging Evidence from Zimbabwe's Resettlement Programme - a Sequel. Journal of Southern African Studies, 27(1), 127-36.

Herbst, J. 1990. State Politics in Zimbabwe. Harare: University of Zimbabwe

IPC for Food Sovereignty. 2006. Agrarian Reform in the Context of Food Sovereignty, the Right to Food and Cultural Diversity: 'Land, Territory and Dignity'. http://www.icarrd.org

Jacobs, P. 2003. Support for agricultural development. No. 4, Evaluating land and agrarian reform in South Africa. An occasional paper series. Cape Town: Institute of Poverty, Land and Agrarian Studies, University of the Western Cape.

Johnston, B. and J. Mellor. 1961. The Role of Agriculture in Economic Development. American Economic Review, 51(4), 56-93.

Kinsey, B. 1999. Land Reform, Growth and Equity: Emerging Evidence from Zimbabwe's Resettlement Programme. Journal of Southern African Studies, 25(2), 173-96.

Kinsey, B. 2003. Comparative economic performance of Zimbabwe's resettlement models. In: M. Roth and F. Gonese eds. Delivering land and securing rural livelihoods: Post-independence land reform and resettlement in Zimbabwe. Harare and Madison: Centre for Applied Social Sciences, University of Zimbabwe, and Land Tenure Center, University of Wisconsin-Madison.

Kydd J., Dorward, A. and Poulton, C. 2000.Globalisation and its implications for the natural resources sector: a closer look at the role of agriculture in the global economy. Commissioned paper. London: Department of International Development.

Lahiff, E. 2003. The politics of land reform in southern Africa. Sustainable livelihoods in Southern Africa, research paper no. 19. Cape Town: Institute of Poverty, Land and Agrarian Studies, University of the Western Cape.

Lahiff, E. 2007a. Redistributive land reform and poverty reduction in South Africa. Working paper for the Livelihoods after Land Reform project: www.lalr.org.za.

Lahiff, E. 2007b. 'Willing Buyer, Willing Seller': South Africa's failed experiment in market-led agrarian reform. Third World Quarterly, 28(8), 1577-98.

Lahiff, E. 2008. Land Reform in South Africa: A Status Report 2008. Cape Town: Institute of Poverty, Land and Agrarian Studies, University of the Western Cape.

Lal, D. 1983. The Poverty of 'Development Economics'. London: Institute of Economic Affairs.

Lipton, M. 1993. Land Reform as Commenced Business: The Evidence Against Stopping. World Development, 21(4), 641-57.

Marongwe, N. 2003. The fast track resettlement and urban development nexus: The case for Harare. In: M. Roth and F. Gonese, eds., Delivering land and securing rural livelihoods: Post-independence land reform and resettlement in Zimbabwe. Harare and Madison, Centre for Applied Social Sciences, University of Zimbabwe, and Land Tenure Center, University of Wisconsin-Madison. 
Marongwe, N. 2009. Interrogating Zimbabwe's Fast Track Land Reform and Resettlement Programme: a focus on beneficiary selection. PhD thesis, University of the Western Cape.

Masiiwa, M. 2004. Post-independence Land Reform In Zimbabwe: Controversies and Impact on the Economy. Harare: Friedrich Ebert Stiftung and Institute of Development Studies, University of Zimbabwe.

McMichael, P. 2008. Peasants Make Their Own History, But No Just as They Please .... Journal of Agrarian Change, $8(2,3), 205-28$.

Metson, J. 1979. Mixed dairying and maize farming in the Nandi high potential areas of Kenya. PhD dissertation. Norwich, UK: University of East Anglia.

Moyo, S. 2000. The political economy of land acquisition and redistribution in Zimbabwe, 1990-1999. Journal of Southern African Studies, 26(1), 5-28.

Moyo, S. 2001. The land occupation movement and democratisation in Zimbabwe: Contradictions of neoliberalism. Millennium - Journal of International Studies, 30(2), 311-+.

Moyo, S. 2007. The land question in southern Africa: a comparative review. In: L. Ntsebeza and R. Hall, eds. The Land Question in South Africa. The Challenge of Transformation and Redistribution, Cape Town: Human Sciences Research Council Press, pp. 6o-84.

Moyo, S. and P. Yeros. 2005. Land Occupations and Land Reform in Zimbabwe: Towards the National Democratic Revolution. In: S. Moyo and P. Yeros, eds. Reclaiming the land: The resurgence of rural movements in Africa, Asia, and Latin America. London: Zed Pres, pp. 165-205.

Murray, C. 2002. Livelihoods Research: Transcending Boundaries of Time and Space. Journal of Southern African Studies, 28(3), 489-509.

Namibia Agricultural Union. 2005. The Namibia Agricultural Union and land reform. Windhoek: Namibia Agricultural Union.

O' Laughlin, B. 2004. Book Reviews. Development and Change, 35(2), 385-403.

Owens, T., J. Hoddinott, and B. Kinsey. 2003. The impact of agricultural extension on farm production in resettlement areas of Zimbabwe. Economic Development and Cultural Change, 51(2), 337-57.

Palmer, R. 1990. Land reform in Zimbabwe, 1980-1990. African Affairs, 89(338), 163-181.

Palmer R. and N. Parsons. 1977. The Roots of Rural Poverty in Central and Southern Africa. London: Heinemann.

Phimister, I. 1988. An Economic and Social History of Zimbabwe, 1890-1948. London and New York: Longman.

Permanent Technical Team on Land Reform. 2005. Strategic options and action plan for land reform in Namibia. Windhoek: Ministry of Lands and Resettlement.

Presidential Land Review Committee Report. 2003. Report of the Presidential Land Review Committee under the Chairmanship of Dr Charles Utete, Volumes I and II. Harare: Government of Zimbabwe

Quan, J. 2000. Land Tenure, Economic Growth and Poverty Reduction in Sub-Saharan Africa. In: C. Toulmin and J. Quan, (eds). Evolving land rights, policy and tenure in Africa. London: Department for International Development, International Institute for Environment and Development, and Natural Resources Institute, pp 31-49.

Rigg, J. 2006. Land, Farming, Livelihoods and Poverty: Rethinking the Links in the Rural South. World Development, 34(12), 180-202.

Republic of Namibia. 1998. National Land Policy. White Paper. Windhoek: Ministry of Lands, Resettlement and Rehabilitation 
Republic of Namibia. 2001. National Resettlement Policy. Windhoek: Ministry of Lands, Resettlement and Rehabilitation.

Rosset, P. 2006. Moving Forward: Agrarian Reform as a Part of Food Sovereignty. In: P. Rosset. R. Patel and M. Courville, eds. Promised Land: Competing Visions of Agrarian Reform. Oakland, CA: Food First Books, pp 301-21.

Rosset P., R. Patel and M. Courville, eds. Promised Land: Competing Visions of Agrarian Reform. Oakland, CA: Food First Books

Rostow, W. W. 1960. The Stages of Economic Growth: A Non-Communist Manifesto. Cambridge: Cambridge University Press.

Sachikonye, L.M. 2003. 'From Growth with Equity' to 'Fast Track' Reform: Zimbabwe's Land Question'. Review of African Political Economy, 30(6), 227-40.

Schuh, C., C. Conroy, J. Grimm, M. Humavindu, C. Kwala, H. Ströbel and W. Werner. 2006. Economics of land use. Financial and economic analysis of land-based development schemes in Namibia. Windhoek: Ministry of Lands, Resettlement and Rehabilitation.

Schultz, T.W. 1964. Transforming Traditional Agriculture. New Haven: Yale University Press.

Scoones, I.1998. Sustainable Rural Livelihoods: A framework for Analysis. IDS Working Paper, 72. Brighton: Institute for Development Studies, University of Sussex.

Scoones, I. 2009. Livelihoods perspectives and rural development. Journal of Peasant Studies, 36(1), 171-96.

Scoones, I. and W. Wolmer. 2002. Crop-Livestock Integration n Africa. In: I. Scoones and W. Wolmer, eds. Pathways of Change. Crops, Livestock and Livelihoods in Mali, Ethiopia and Zimbabwe. Oxford, U.K. and Portsmouth (N.H.): James Currey and Heinemann, pp1-31.

Scoones,I. S. Devereaux and L. Haddad. 2005. Introduction: New Directions for African Agriculture. IDS Bulletin, 36(2), 1-12.

Sender, J. and D. Johnston. 2004. Searching for a weapon of mass production in rural Africa: Unconvincing arguments for land reform. Journal of Agrarian Change, 4(1\&2): 142-64.

Sherborne, R. 2004. A rich man's hobby. In: J. Hunter (ed), Who Should Own the Land?. Analysis and Views on Land Reform and the Land Question in Namibia and South Africa. Windhoek: Konrad-AdenauerStiftung and Namibia Institute for Democracy, pp8-18.

Shackleton S., C. Shackleton and B. Cousins, 2000. The economic value of land and natural resources to rural livelihoods: case studies from South Africa. In: B. Cousins (ed), At the Crossroads: Land and Agrarian Reform in South Africa into the $21^{\text {st }}$ century. Cape Town and Braamfontein: Programme for Land and Agrarian Studies, School of Government, University of the Western Cape and National Land Committee, pp 35-67.

Tapscott, C. 1995. War, peace and social classes. In C. Leys and J. Saul, eds. Namibia's Liberation Struggle. The two-edged sword. London: James Curry.

Throup, D. 1987. The Economic and Social Origins of Mau-Mau, 1945-1953. London: James Currey.

Turner, S. and H. Ibsen. 2000. Land and agrarian reform in South Africa: a status report. Research Report No. 6. Cape Town: Institute of Poverty, Land and Agrarian Studies, University of the Western Cape.

United Nations Development Programme. 2002. Zimbabwe Land Reform and Resettlement: Assessment and Suggested Framework for the Future. Interim Mission Report. Harare: United Nations Development Programme 
Van den Brink, R., G. Thomas and H. Binswager. 2007. Agricultural land redistribution in South Africa: towards accelerated implementation. In: L. Ntsebeza and R. Hall, eds, The Land Question in South Africa. The Challenge of Transformation and Redistribution. Cape Town: Human Sciences Research Council Press, pp152-201.

Weis, Tony, 2007. The Global Food Economy: the Battle for the Future of Farming, Halifax and London, Fernwood Publishing and Zed Books.

Werner, W. and B. Kruger. 2007. Redistributive Land Reform and Poverty Reduction in Namibia. Paper for Livelihoods after Land Reform research project, www.lalr.org.za.

Williams, G. 1996. Setting the agenda: a critique of the World Bank rural restructuring programme for South Africa. Journal of Southern African Studies, 22(1), 139-66.

Wolmer, W. and I. Scoones. 2000. The science of 'civilized' agriculture: The mixed farming discourse in Zimbabwe. African Affairs, 99(397), 575-600.

Wolpe, H. 1972. Capitalism and Cheap Labour Power: from Segregation to Apartheid. Economy and Society, 1(4), 425-56.

World Bank. 2007. Agriculture for Development. World Development 2008. Washington: World Bank.

Yawitch, J. 1981. Betterment: The Myth of Homeland Agriculture. Johannesburg: South African Institute of Race Relations. 